\title{
Learning Processes and Agency in the Decarbonization Context: A Systematic Review through a Cultural Psychology Point of View
}

\author{
Nicola Stocco (D), Francesco Gardona, Fulvio Biddau and Paolo Francesco Cottone *(D) \\ Department of Philosophy, Sociology, Education and Applied Psychology (FISPPA), University of Padova, \\ 35122 Padova, Italy; nicolastocco6@gmail.com (N.S.); francesco.gardona@gmail.com (F.G.); \\ fulvio.biddau@unipd.it (F.B.) \\ * Correspondence: paolo.cottone@unipd.it; Tel.: +39-049-8276625
}

Citation: Stocco, N.; Gardona, F.; Biddau, F.; Cottone, P.F. Learning

Processes and Agency in the

Decarbonization Context: A

Systematic Review through a Cultural Psychology Point of View. Sustainability 2021, 13, 10425. https:/ / doi.org/10.3390/su131810425

Academic Editor: Ralph Hansmann

Received: 30 June 2021

Accepted: 15 September 2021

Published: 18 September 2021

Publisher's Note: MDPI stays neutral with regard to jurisdictional claims in published maps and institutional affiliations.

Copyright: (c) 2021 by the authors. Licensee MDPI, Basel, Switzerland. This article is an open access article distributed under the terms and conditions of the Creative Commons Attribution (CC BY) license (https:// creativecommons.org/licenses/by/ $4.0 /)$.

\begin{abstract}
In the scientific literature on energy transition toward decarbonization, the learning process is often described as a preferred way to achieve change. However, despite a large number of theoretical and empirical endeavors, a systematic understanding of the process is still lacking due to the diversity of disciplines and approaches and to the multi-layered nature of the phenomenon. The aim of this systematic review is to highlight the dimensions of learning processes from a cultural psychological point of view in order to understand and assess different planes of the relation between humans and technology. We thus explore the literature following the PRISMA protocol. Through a narrative synthesis, we critically assess the theoretical and methodological advancement, the presence of cultural determinants, the value ascribed to agency, and the depoliticization risk. We found that: theories and methodologies still lack systematicity and concordance in their application; learning processes are studied with little focus on the context and are mostly treated as facilitators; agency mostly lacks a psychosocial focus, despite the exploration of multi-level problems; and the depoliticization of learning is a matter of fact. Nevertheless, positive examples are present, although they are few. Epistemological and political implications are discussed, and a psychosocial conception of agency is proposed, together with a reflective stance for researchers.
\end{abstract}

Keywords: situated learning; social learning; learning in transition; decarbonization; depoliticization; cultural psychology; psychosocial agency

\section{Introduction}

Global warming is a major threat to humankind, as acknowledged by the 2018 IPCC report, which also recognized fossil-based energy resources as one of the main causes of climate change [1]. There is an urgent need to drastically reduce greenhouse gas (GHG), the output of carbon-related energy sources, in order to avoid a catastrophic scenario in the near future. The decarbonization pathway, namely, replacing fossil energy sources with renewable energy sources, is one of the most discussed and relevant transition processes in this regard [1]. This energy transition process is inherently complex because it involves different dimensions, from social and symbolic to the industrial system and economic level $[2,3]$. Within this socio-technical approach to transition, the relation between human beings, the environment, and technology is central [3]. In this context, the multi-level perspective (MLP) is proposed as a global theoretical framework able to assess all of the processes involved in systematizing transition [2,4,5]. The explicative potential of MLP lies in the interaction between three elements that provide an explanatory model of historical energy transition: socio-technical landscapes, as the long-term secular development process; regime, as the incumbent socio-technical system; and niches, as the main drivers of innovation [6,7]. In this way, the theory attempts to cover elements that are neglected by mainstream socio-technical policy and governance approaches, such as the role of culture 
and political struggle as fundamental parts of complex transition dynamics $[7,8]$. Recent findings provide suitable empirical validation, imparting the theory with a normative status that can influence policy studies and governance settings [6,9]. Despite its empirical value, the theory has received several criticisms $[6,10,11]$, particularly regarding the lack of consideration of agency in the transition process, emphasizing institutional knowledge over grassroots knowledge [11]. This reflects a lack of consideration for the socio-psychological process of knowledge production, as illustrated by the recent growth in the literature on the psychosocial dimension of transition [12-14]. As Bogel and Upham [12] show in their review, the focus of agency relies on collective actors or on individual actors: how the structural factors influence the individual factors and vice versa remain implicit or unexplained. Another problem related to agency is that the politics of its usage primarily focuses on the acceptance and experimentation of large-scale technology instead of exploring the actor's participation as a means to develop an energy democracy agenda with local resources and values $[15,16]$. As a consequence, agents are treated as mere consumers, and the human dimension serves as a useful tool to produce a commodified subjectivity resilient to the latest green-capitalism transfiguration instead of focusing on enhancing emancipated agency [17]. In addition to these criticisms of the theory, the objective of MLP to cover the neglected dynamics of transition is challenged by the epistemic community context, which views the dominance of STEM science in the fields of transition studies as a legitimate producer of scientific evidence. Scholars are prompted to exclude social sciences and humanities by material lock-in conditions posed by financial supporters and commissioners in order to reach a "hard" and measurable outcome $[18,19]$. This could be seen as a depoliticization process [20] by research design.

A number of scholars have attempted to overcome these criticisms [21] by: reframing [6,11] or specifying [9] the epistemological foundation toward a more agency-driven approach, redirecting the research agenda [22], and shifting to a more systematic comprehension of the power relations [23]. However, the development of these studies is ongoing and thus still conceptually confusing, with several blind spots $[10,24]$ and a serious risk of reproducing a depoliticized research activity [18]. In this context, the learning process is one of the blind spots: its inherent intersubjective nature challenges the structural basis of MLP, and despite notable citations from scholars [4,22], the learning process is still a "black box" that needs to be opened in order to exploit the full potential of the theory [24,25]. In this regard, recent reviews [25-29] highlight several problems in learning in transition studies. Gerlak et al.'s [28] results indicate that in the environmental science context, the research design is not always a matter of concern for scholars: learning is not always defined, theoretical approaches are often implicit, the methodology is often "limited to anecdotal and subjective assessments" [28] (p. 14), and overall knowledge building is lacking due to an unclear link between evidence that influences learning and outcomes. van Mierlo and Beers [27] found that none of the four major learning study traditions (collaborative learning, organizational learning, social learning, and interactive learning) conceptually cover the complexity of the socio-technical transition. Instead, they propose a link between these major learning traditions and their application within the MLP's landscape-regime-niche scheme. Goyal and Howlett [29] found that actors participating in learning in transition are not divided in their contextual network of activity, so they are the object of learning. The authors propose a connection between collective actors (technological constituencies, epistemic communities, instrument constituencies, and advocacy coalitions) and the object of these activities. Van Poeck, Ostman, and Block [25] found three major blind spots in the literature: a lack of conceptual clarity, a weak empirical knowledge base, and the need for a suitable analytical approach. Drawing from John Dewey's work, they propose a pragmatist educational theory, which perceives the intrapersonal, interpersonal, institutional, and material dimensions as factors that connect the learning process to societal transformation. In a more recent article [30], they operationalized their approach in empirical research. In sum, the reviews highlight different elements, such as theoretical grounding and the consideration of actors and contexts, that should be taken into account by a scientific inquiry 
on the process of learning. A relational and situated approach to learning is ultimately found to be the most relevant and necessary to fill the gap in learning in transition studies, focusing on the everyday life context, political issues, conflict, implicit learning, grassroots innovation, informal learning process, and re-evaluation of indigenous knowledge [26]. The definition of learning provided by van Mierlo et al. [26] describes it very well: "[...] we perceive learning in transitions as a process of acquiring and generating new knowledge and insights, and of meaning-making of experience in communicative interaction, in a reciprocal relationship with the social, (bio)physical and institutional context. Moreover, it is a non-linear, iterative process in which ideas and possibilities for collaborative action are developed, experimented with and pursued in a diversity of networks" (p. 253).

These insights act synergically with the cultural psychology approach that we discuss here. The quest for a cultural approach to transition, starting from a psychosocial foundation [31], aims to reframe the way in which the individual/collective problem is viewed in the scientific community [32]. Starting from the consideration of artifacts as an expression of culture and embedded cognition [33,34], this approach is "[...] an attempt to overcome the dichotomies between technical and human and social and individual accounts of energy transition" [32] (p. 2). The focus is on a situated perspective and multiple planes (societal, community, individual) that afford the opportunity to treat the cultural factors not only "as external data embedded in the organization of material and social life that influences individual feelings, judgments and behaviors but also as a constitutive part of the individual mind" [32] (p. 3). The body of literature that applies this framework is growing [35-40]: for example, Biddau et al. [35] analyzed the social representation of sustainability and the relevance of collective identity in a grassroots movement, showing the original continuity between community, individual and societal planes in the link between emotional coping, political engagement and the vision of the future. Along the same line, Kim et al. [36] analyzed the way in which collective memory influences the acceptance of new technology in a community, stressing the cultural impact of place attachment.

A cultural psychological approach to transition prioritizes psychosocial agency, viewing the cognitive process as discursive phenomena that are necessarily mediated by artifact production and the historical-material conditions in which they are situated. In this sense, learning is disentangled from the cognitivist perspective of development, which regards learning as a process that fills the void of a normative mental model or an institutional set of notions. As an intersubjective sense-making process, learning has to address the cultural dimension embedded in materialities and the situated context in which it emerges [41]. In this way, learning could be viewed as a broader process of socialization that necessarily involves a specific type of change, inasmuch as identification with a determined community of practice leads to novel cultural appropriation [41-43].

By examining the state of the art of the literature regarding the transition to decarbonization and the learning process, this review aims to explore how studies have framed the role of agents in the production of effective change. We argue that changing the focus from the transition itself and starting directly from the human dimension, such as the learning process, can promote the active role of agents in the production of effective societal change, thus challenging the passive model used in the transition literature, with the consideration of depoliticized agency and theoretical dispersion.

\section{Materials and Methods}

Environmental issues are fertile ground for the study of learning because they are characterized by high levels of uncertainty associated with cross-scale feedback, unclear problem definition and resolution, and diverse policy interests $[44,45]$. Therefore, the objective of this article is to examine how "learning", as an analytical device and conceptual lens, has been explored in the last 5 years of the literature on the transition toward decarbonization [28]. To operationalize the general aim, we subdivided it into three research questions that reflect the topic cited above and serve as analytical criteria: 
1. How has the theoretical and methodological development of studies concerning learning evolved?

2. Are dimensions compatible with a psycho-cultural approach taken into consideration? 3. What kind of value is attributed to agency? Is there a risk of depoliticization?

To achieve the goal of this research, we performed a systematic review, a family of research approaches to analyzing secondary data (secondary research) that bring together the findings of primary research to answer a research question [46]. Systematic reviews can therefore be defined as "a review of existing research using explicit, accountable rigorous research methods" [47] (p. 4). Our systematic review was performed using a classic protocol consisting of a set of processes that can be divided into distinct but interconnected phases. In particular, we adopted the PRISMA statement and guidelines (preferred reporting items for systematic review and meta-analyses), which consists of several steps: Identification, Screening, Eligibility, and inclusion [48]. We summarize the procedure in Figure 1.

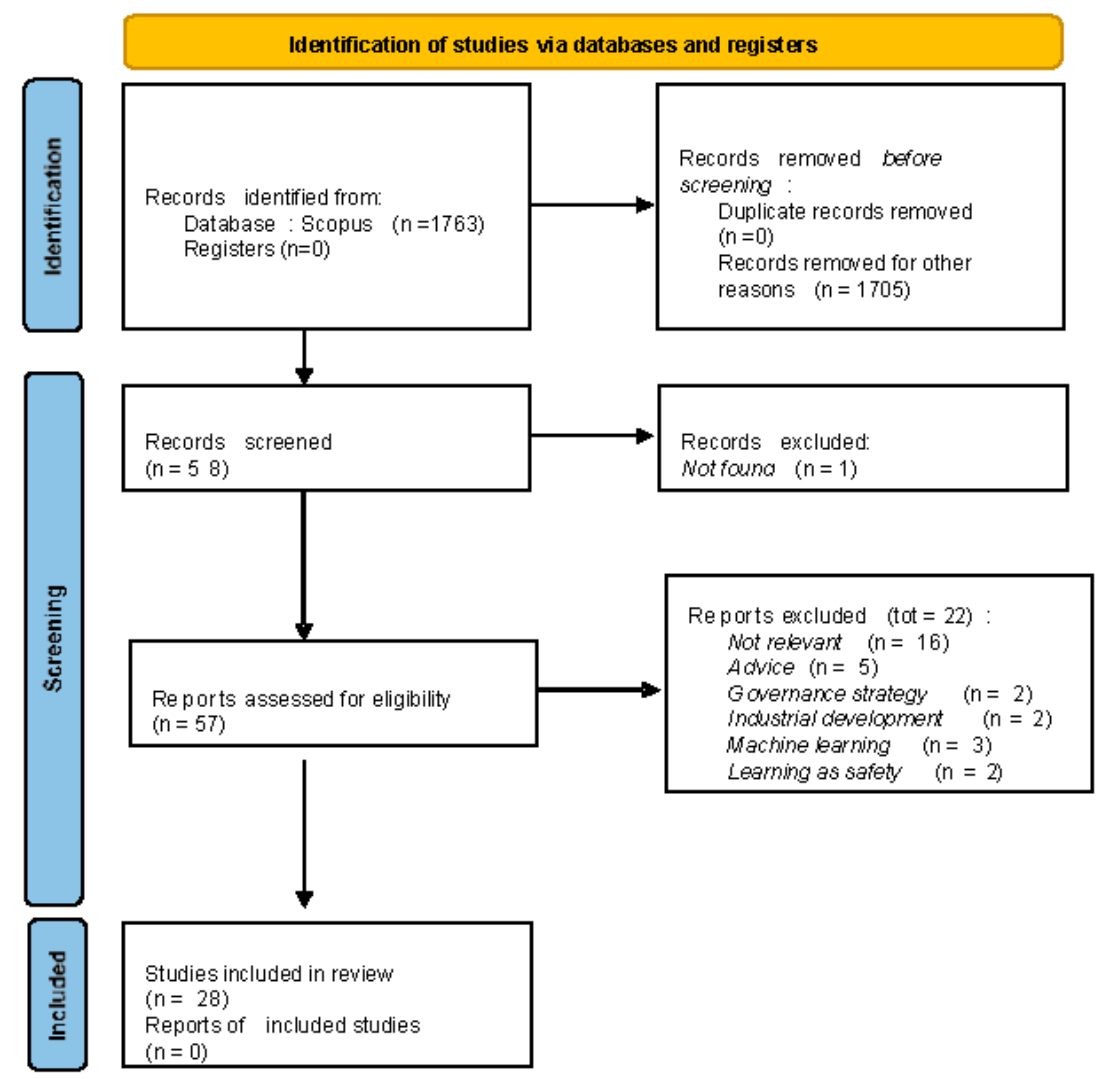

Figure 1. Flow diagram of PRISMA procedure.

We started the systematic review with the identification phase by selecting studies that cite an association between sustainability and any type of learning process. Therefore, to identify relevant studies, we built an initial database consisting of 1763 articles, which were found by using the search string in the Scopus database and were published between 2015 and the first half of 2020. For the construction of the database, we included perspectives from individual, group/community, and social levels [32] and the various ways in which the decarbonization process can be addressed. Selected query: TITLE-ABS-KEY (psycho* OR cultur* OR public* OR citizen* OR communit* OR household* OR individual OR collectiv* OR social AND decarbon* OR low-carbon OR post-carbon OR zero-carbon OR "carbon neutral" OR coal) AND (PUBYEAR > 2014) AND (LIMIT-TO (DOCTYPE, "ar")) AND (LIMIT-TO (SUBJAREA, "SOCI") OR LIMIT-TO (SUBJAREA, "MULT") OR LIMIT-TO (SUBJAREA, "PSYC")) AND (LIMIT-TO (LANGUAGE, “English")). 
In the screening phase, we aimed to identify all articles that use learning as the relevant object of study. For this purpose, we searched for the word "learning" in the abstract, title, and keywords. We found 58 articles that fit this first criterion.

For the eligibility phase, the 58 articles previously identified were subjected to a verification process by a team of three researchers to ensure that they meet the selection criteria. This was conducted in two stages: in the first stage, the titles and abstracts were checked to determine if the study was relevant to the purposes of our research; in the second stage, a complete copy of each article was acquired to complete the screening step. The in-depth reading of the abstracts and contents of the various articles allowed us to establish further exclusion criteria, which led to the contextualization of the word "learning" in articles that use it to describe a human-oriented process and not as a purely technical term. Thus, we excluded articles relating to: machine learning $(n=3)$, learning as a governance strategy $(n=2)$, learning in industrial development $(n=2)$, learning for miner safety $(n=2)$, learning as advice or rhetorical usage $(n=5)$ and general unrelated usage $(n=16)$; thus, 35 articles were retained after this step.

Finally, in the inclusion phase, we systematically recorded the information in the articles by applying a coding grid. The grid was constructed following the analysis methodology used by Gerlak et al. [28]. They designed a codebook with multiple questions to evaluate articles according to three main criteria: first, they expect to see explicit research questions or goals related to learning, as well as the theoretical grounding of the questions or goals [49,50]; second, the cases and context for the research should be clearly identified, and the empirical research methods should be explicit and transparent to the reader [49]; third, they expect to see overall advancement in our knowledge about the phenomenon of interest through the literature as a whole [28].

Drawing from this coding method used by Gerlak et al. [28], we designed a codebook organized into three sections that reflect our research questions' topics: (1) theory and methodology, in which we acknowledge the theoretical and methodological limitations of the existing learning literature [27,28]; (2) cultural and material elements, in which we identify the cultural dimension surrounding learning, highlighting the drivers and barriers [51] that can enhance or inhibit learning; (3) psychosocial and political elements, in which we discuss the different aspects of agency in the learning process, focusing on the power relations among actors [23] and the way that agency is framed and used in the article. For each section, we developed multiple questions ( $\mathrm{n}$ tot $=18$ ) to systematize the variety of content of individual articles. We formulated the questions so that answers were dichotomous (yes or no) or open-ended, with the ability to describe observations. To enhance the probability of an emergent topic, we provided the opportunity to comment freely on every question. To minimize the likelihood of reviewer bias in the coding process [52] due to differing interpretations, each of four respondents coded a single article, and the responses were then compared; we discussed the questions according to the intersubjective variability that emerged from the answers and modified them in order to reach a unique agreement. The coding phase made it possible to eliminate 7 additional articles due to their irrelevance to the topics of the review, resulting in 28 final coded articles (cfr. Appendix A for the complete record of the articles reviewed).

\section{Results}

\subsection{Research Landscape}

The 28 coded articles appeared in 21 different journals. An examination of the number of articles per year indicates that the articles on learning in our sample have increased exponentially in recent years, as shown in Table 1 . Most of the articles were published by Elsevier (eight articles), MDPI (six articles), and Routledge (five articles), while the fewest were published by Emerald Publishing Limited and Adult Learning Australia Inc., each of which published at least two articles. The publishers that have published only one article are Sage Publications Ltd., University Of Toronto Press Inc., Kassel University Press Gmbh, and, finally, Linkoping University Electronic Press. Furthermore, most of the 28 papers are 
from UK universities (7), followed by Netherlands universities (5), Australian and Finnish universities (4), Canadian universities (3), and German universities (2). U.S. universities are not represented in our data, while a Chinese university is represented by an article only through collaboration with other universities in other countries. Our data contrast with the data provided by the Scimago Journal and Country Rank, as these nations, at the overall university level, are always in the top three places of the ranking for the number of documents published, both for the social sciences in general and for the specific areas of learning and sustainability, such as education and geography, planning and development, in the years 2015-2020 (Appendix B). Based on these data, we cannot confirm if the trends found are representative of the entire population of articles, as we did not perform random sampling; however, the data identified through our non-probabilistic sampling approach are highly relevant for the specific purposes of our study.

\subsection{Aggregated Response Results}

In the following section, we present the aggregated results for each question. Each subsection begins with a rationale that guides the overall analysis. In Appendix B, Table A3, we synthesize the complete results with article references.

\subsubsection{Theory and Methodology Rationale}

With this set of questions, we evaluate the theoretical advancement and methodological typology used. One of the problems identified in reviews of learning in transition is a lack of conceptual clarification. For instance, Gerlak et al. [28] highlight that explicitly describing the theoretical approach is not a common practice among scholars. Another problem pointed out by Gerlak and collaborators is the lack of a clear definition of learning: a large number of articles refer to "learning" without connecting it to a theory, laying a foundation for possible misunderstandings. In fact, the interpretation of results and outcomes derives from theoretical underpinnings, so implying rather than specifying these aspects could lead to a more problematic field of inquiry. In addition, in order to achieve a socio-psychological understanding of threshold events, it is useful to distinguish between the emic and etic dimensions of the production of knowledge.

1. What is the theoretical approach used in the article?

The purpose of this question is to identify the range of theoretical frameworks used in the articles. Due to the broadness of the disciplinary range, we encountered several approaches to the meaning of "theory" in the research design. Following Sovacool and Hess [53], we defined a theory as any reference to: general presuppositions, models, and frameworks that specify a precise view in the research design. Thus, as detailed in Table A3, we found that 10 articles (36\%) [54-63] used a theory that directly addresses the function of the learning process. These studies include perspectives on social learning [55] and situated learning $[54,57,58,62]$. Other theories used are problem-based learning $[60,61]$ and social movement learning theory [56,59,63]. Conversely, 13 (46\%) articles [64-76] use a theory that does not directly relate to learning. In this context, a large part comprises socio-technical transition-related theories, such as strategic niche management $[65,66,71]$, transition management $[68,70,73]$ and the agent-based model [74]. Other articles use a strategic spatial planning approach [64], Bandura's moral disengagement theory [76], and strategic talent development [69]. Some of the articles attempt to integrate different theoretical perspectives: theory of planned behavior with value-belief-norm theory and the theory of place-protective action [67], techno-scientific cognitive learning with situated learning [57], theory of frugality in decision making with the theory of process in local capability formation in explicit and tacit knowledge transfer and theory of absorptive capacity for new knowledge [72]. Finally, five articles (18\%) refer to a very broad or eclectic theoretical approach that results in a stand-alone code: risk communication [77], historical approach to evolutionary economic analysis [78], crossover point approach [79], lesson learning practices [80] and qualitative and quantitative approach to the creation of a hypothetical model [81]. 
Table 1. Most comprehensive definitions of learning divided by typology.

\begin{tabular}{|c|c|c|}
\hline Typology & Definition & References \\
\hline $\begin{array}{l}\text { Social learning } \\
\text { (in transitions } \\
\text { studies) }\end{array}$ & $\begin{array}{l}\text { Learning processes contribute to the generation of knowledge and expertise on how to improve } \\
\text { innovations from experiments. However, besides this "first-order learning", there is also a form } \\
\text { of "second-order learning", in which niche actors reflect on ongoing niche development and } \\
\text { ongoing practices and critically question the assumptions of regime systems, learning about } \\
\text { alternative cognitive frames and alternative ways of valuing and supporting niche development. }\end{array}$ & [65] \\
\hline Social learning & $\begin{array}{l}\text { Social learning: a process where two phenomena occur: first, changes in understanding appear in } \\
\text { the individuals involved; and second, changes occur that go beyond the individuals and become } \\
\text { situated within wider social units. Both these phenomena happen through direct and/or indirect } \\
\text { social interactions among actors within a social framework. }\end{array}$ & $\begin{array}{l}{[64]} \\
\text { Other } \\
\text { examples: } \\
{[70,71,80]}\end{array}$ \\
\hline $\begin{array}{l}\text { Situated } \\
\text { learning }\end{array}$ & $\begin{array}{l}\text { "Learning in the sense we use here means learning by people acting collectively to bring about } \\
\text { radical and emancipatory social change". Three key areas of activists' adult learning, } \\
\text { "instrumental learning-providing skills and information to deal with practical matters, } \\
\text { 'interpretive learning-which has a focus on communication', and 'critical learning' -activists } \\
\text { learn problem-solving skills through reflection new meaning is produced". Informal learning } \\
\text { occurs through the experience of being in a campaign and largely through reflection and action } \\
\text { rather than in non-formal learning contexts such as workshops and training. Learning is } \\
\text { embedded in the discursive interactions between members of the group; they are key pedagogic } \\
\text { moments; they are moments of reflexive praxis and dialogic reciprocity, where } \\
\text { knowledge-making occurs. }\end{array}$ & $\begin{array}{l}{[63]} \\
\text { Other } \\
\text { examples: } \\
{[55,58]}\end{array}$ \\
\hline $\begin{array}{l}\text { Experiential } \\
\text { learning }\end{array}$ & $\begin{array}{l}\text { Learning effects take place both on supply and demand sides. On the supply side, they result } \\
\text { from learning-by-doing, referring to increasing returns from knowledge accumulation and } \\
\text { refined organizations. In this way, higher quality products and incremental innovations become } \\
\text { cost-effective. On the consumption side, learning-by-using reduces the uncertainty of } \\
\text { technology's costs and performance, decreases service costs, and increases operation efficiency. }\end{array}$ & $\begin{array}{l}{[75]} \\
\text { Other } \\
\text { examples: } \\
{[61,74]}\end{array}$ \\
\hline
\end{tabular}

2. Is it conceptual or empirical research?

The purpose of this question is to assess the overall research design of the articles, distinguishing between a research design based on empirical data and a design that draws principally on conceptual insight and reasoning. We found only 4 conceptual design articles [73,75,78,80], while the empirical design is used in 24 articles (86\%) [54-72,74,76,77,79,81]. A high prevalence of case studies (15) is reported, making it the most frequently used methodology for studying learning [54,55,58-65,69-72,74,79,81].

3. What is the definition of learning stated in the article?

In the majority of the screened articles $(n=17 ; 61 \%)$, the definition of learning is not indicated $(n=7.25 \%)[62,69,72,73,76-78]$ or is just superficially cited $(n=10 ; 36 \%)$. In this case, we found articles that only mention the type of learning that they take into account, for example, social learning [79,81], cognitive and situated learning [57], and lifelong learning approaches [54]. Other articles [56,59,60,67] do not refer explicitly to a specific type of learning but to a general process of acquiring knowledge and constructing meaning. In other articles $[66,68]$, the learning process is understood as a necessary aspect of the transition process but is not further explored per se. In the remaining cases $(n=11.39 \%)$, we found at least one explicit definition of the learning process. We found a preference for broad definitions of learning, such as social learning, over the other approaches' definitions, as illustrated in Table 1.

\section{What are the aim/scope/research questions?}

The purpose of this question is to determine if the learning process is a central part of the research design. Only nine articles $[56-59,61,63,66,71,80]$ cited the learning process as a central part of the research project. These articles refer to different specific aims: learning outcomes [61,71], exploration of learning dimensions and processes [56-58], and focus on actors and lived experience $[59,63,66,80]$. In eight articles, we found that the aim references the learning process in an implicit manner, referring to collective or individual processes of 
negotiating meaning, awareness goals, or knowledge co-creation $[55,62,64,67,69,70,76,81]$. The remaining 11 do not remotely address learning [54,60,65,68,72-75,77-79].

5. Are there any references to transition theories?

Only nine articles (32\%) refer to a transition-related theory, such as strategic niche management $[65,66,71]$ or transition management $[68,70,73]$. In some cases, the transition is cited but not linked to the theoretical approach used $[54,75,78]$.

6. Is the research conducted from an emic or etic perspective?

The purpose of this question is to assess the type of knowledge that scholars take into account when they design their research, distinguishing between emic and etic methodological perspectives. Emic refers to a bottom-up methodology, in which knowledge that emerges from participants is used to build a model or a theory; etic refers to top-down methodology, in which the extracted data are fit to a generalized model or theory. The majority of articles adopt the emic perspective $(n=20 ; 71 \%)[54-59,61-68,70-72,75,76,80]$ over the etic perspective $(n=8 ; 29 \%)[60,69,73,74,77-79,81]$.

7. Is the object or scope of learning explicit?

In eight articles (29\%) [54,62,68,72,74,77,79,80], it was not possible to identify the purpose or object of learning. In these specific cases, the aim of learning was taken for granted. However, in 20 cases (71\%) [55-61,63-67,69-71,73,75,76,78,80], the purpose or object of learning is explicit. The most recurring theme with regard to the stated purpose is to increase awareness of specific topics, such as decarbonization/low carbon $[59,61,64,69,73]$, generic environmental [55], and self-agency conscientization [56]. In other cases, the aim involves applying the socio-technical approach to the study of transition, indicating development from niche to regime $[65,66,70]$ and regime change $[71,78]$ as the object of learning. For the purpose of learning, a collective stance is indicated as a generator of new knowledge for social change [58,63] and a contribution to societal learning [57]. Conversely, the individual stance is represented by aims such as enhancing the decisional process [75] and cognitive and behavioral changes [55,76,81]. Lastly, we identified learning purposes as facilitating the co-creation of knowledge [67] and expanding the frame in which sustainability problems are defined [60].

\subsubsection{Cultural and Material Rationale}

With this set of questions, we evaluate the relevance of cultural elements and their use in the research design. Within a cultural psychological approach, cultural dimensions involve elements such as practices, imaginaries, memories, values, beliefs, norms, and material elements such as the body, artifacts, or the environment. These elements embody the cultural dimension that allows the transmission and co-construction of knowledge, which is necessarily mediated. From this perspective, learning is a sense-making process that necessarily involves the cultural dimension [26]. Neglecting these aspects could lead to a misunderstanding of the learning dynamics in transition, such as cultural barriers to transition [51].

8. Are there any cultural elements taken into account?

Only 16 articles (57\%) [54-59,61,63-67,69-73] include at least one cultural element in the definition of relevant objects for the research. For instance, place-related features are cited as relevant elements: London [54,55], Finnish [66] and Australian [70] urban contexts; Canadian energy context [73]; and Cadore's environmental specificity [64]. Other cultural elements involve the development of local practice toward integration of diversities [58]; cross-cultural comparison between transport infrastructure [72]; learning as the generation of community culture in situations of protest $[56,59,63]$; manipulation of niche norms about new technologies [71]; leader as an agent of change in organizational culture [69]; scientific literacy [67]; and the usage modality of novel smartphone devices [61]. 
9. Is the learning process tied to the use of artifacts or material elements?

The use of artifacts is strictly related to the issues of energy transition, and yet fewer than half of the included articles take them into consideration $(n=13,46 \%)[55,57,59-61,64,67,68,71,72,75,77,81]$. However, among those that do not refer to material elements as part of the learning process, two articles mention that these material elements require further investigation $[69,73]$. The articles that take artifacts into consideration focus on: machinery and specific tools for collecting data in the energy field [60,67], place-related images [64], sustainable mobilityrelated artifacts (electric vehicles [75], electric bikes [81], light rail transport [72]), residential buildings [71], digital platform for technologically enhanced learning [61], shared community gardens [55], computer communication programs [68] and information brochures [77].

10. Are there any factors that drive or hinder the learning process?

Most of the articles $(n=24 ; 86 \%)$ [54-63,65-67,69-72,74-77,79-81] mention elements that drive or hinder learning. Only two of these articles mention elements that impede learning, namely, structural barriers imposed by power relations [58] and individual responsibilities and institutional barriers [55]. Twenty-one articles cite facilitating elements, most of which are only mentioned and not organically incorporated into the research design. Among these articles, facilitators are regarded as catalysts of learning as a cognitive process $[74,77,81]$ with a particular interest in the "second loop" of learning [54,71]. Others take into account the non-formal context as a facilitator of learning, focusing more on practice and the dialogical dimension [58], such as contact with an extra-academic firm for an engineering student [60]; the social movement context such as protests and activism [56,59,63]; the organizational context [69]; or the research context itself, such the workshop in the first phase of research [79], the use of scenarios as a form of a learning plan [62], the role of researchers as the ultimate (and first) facilitators [70] or the role of the learning process itself as a facilitator [67,76]. Other articles refer to material facilitators, such as new railway structures for poor and marginalized people [72] or digital devices in the school context [61]. Other studies consider the learning process itself to be a facilitator of the larger process of transition [57], sometimes tied to policy management [75,81].

11. Is the learning process explicitly related to an irrational dimension?

Only six articles (21\%) mention an irrational, unconscious, or hidden dimension of learning, but it has yet to be deeply analyzed [55,56,76-79].

\subsubsection{Psychosocial and Political Rationale}

The purpose of this set of questions is to evaluate the use of agency and the possibility for depoliticization. Learning processes in the energy transition context have direct implications for agency, that is, the capacity of actors to act and take part in their environment $[9,26]$. In energy transition studies, the agency issue is addressed mainly from a collective point of view. Conversely, the individual agency stance focuses on cognitive processes and behavioral outcomes [12]. A psychosocial conception of agency is useful to address issues such as power relations in the energy transition context because it connects individual processes with societal dynamics. In this regard, agency is not always equally distributed among actors, raising the political issues of emancipation and justice [23]. This may be taken for granted by scholars, implying political neutrality that is functional to the implementation of a certain policy or intervention; this depoliticization process can lead to the neglect of possible learning processes, such as learning from conflict, indigenous knowledge, and grassroots innovations.

12. In which context are the actors taken into account?

The contexts analyzed in the articles range from political $[65,75,80]$, industrial and organizational $[60,69,74]$, everyday life, urban, mobility, household context $[57,62,66,68,70-73,81]$, community $[54,55,58]$, activism $[56,59,63]$, scholastic and educative $[61,67]$ and not specified [77]. 
13. Which social level is involved in learning?

Following a psychosocial approach, we classify the levels involved in the learning process, starting from an intrapersonal focus (9) $[55,61,63,64,67,69,76,77,79]$, followed by an intersubjective focus (4) $[56,59,60,67]$, community/group focus (12) [54-56,58-61,63,66,69,70,81] and societal focus (14) $[57,62,64-66,68,70-75,78,80,81]$. The number of social levels listed exceeds the number of articles because, as we noted, the focus on social level shifted throughout some of the articles: the learning process studied through an individual focus became relevant to a social sphere, sometimes explicitly and other times implicitly. In these cases, we noticed a consistent reference to the dual action of agency that is otherwise not able to provide a sufficient explanation of the learning dynamics [55,56,59-61,63,64,66,67,69].

14. Is the learning process referred to as a form of change?

Although the learning process involves a dimension of change, its use as such is not obvious. Indeed, we identified seven articles (25\%) that do not refer to the change dimension. Some of them refer to learning as more of an adaptation to an existing paradigm, such as: adaptation to corporate culture [69], feedback system to reinforce a pre-existing mechanism [74], acceptance of an extractive project in order to control conflicts [80] and filling the gap of competencies necessary to solve extra-academic stakeholder problems [60]. A total of 21 articles $(75 \%)[55,56,58,59,61,63-73,75,76,78,79,81]$ referred to a learning process that involved change toward a novel perspective or a mediated synthesis toward a common agreement between the participants. Examples of these types of changes vary from cognitive change [71,81], change toward pro-environmental behavior [61], cultural, political and societal change $[56,58,59,63,65]$, and habits [75].

\section{Who are the actors involved?}

To characterize the actors, we chose the dimension of expertise as a pivotal object on which the research designs on learning are built. We found that some articles had a clear distinction between experts and non-experts, that is, between the owner of the knowledge and the passive subjects who have to learn the specific subject matter. We found that the experts in these studies are entrepreneurs [73], policy makers [57,64,74,75,80], scientists [67] and managers [69]; non-expert actors are divided into regular citizens [67,76], final users of a technological service [71], employers [69], households [74], farmers [79], prosumers [81] and students [60,61]. In other articles, the knowledge is mediated and distributed among participants outside of a hierarchical structure, such as local residents [70], people in a community of practice [55], activists [54,59,63], and science citizens [67].

16. Is the learning process referred to as a possibility for the emancipation of the actor involved?

By emancipation, we mean the degree of freedom of the actors involved in the learning process and the resulting possibility for their action in their particular setting. Most of the articles $(n=19 ; 68 \%)[54,55,57,58,60,62,64-66,69,71,73-75,77-81]$ do not engage with emancipation-related problems. Some articles move toward the inclusion of actors, but in the end, they do not go beyond the use of agency as a means to reach an aim that is pre-defined, not co-constructed. Only nine articles (32\%) $[56,59,61,63,67,68,70,72,76]$ propose accounting for social positions, knowledge, and possibilities of actors in order to enhance their capacities to act in their context.

17. Are there any elements that appear as power relations within the learning process?

Most of the reviewed articles $(n=19 ; 68 \%$ ) [55,57,60-62,64,66,67,69-71,73,74,76-81] do not address power relations that gravitate toward the learning process. In these cases, power relations are understood as incumbent variables or epiphenomena instead of structural elements. In the remaining articles $(n=9 ; 32 \%)[54,56,58,59,63,65,68,72,75]$, the power relations are included organically and serve as a framework to define the related learning issues. In these articles, a theory is provided in order to explain the position of a power relation in the learning process. For instance, Larri and Whitehead [59] problematize age 
and sex in activism, showing how the power relation can be overturned in a learning context.

18. Is the use of results explicitly stated?

The purpose of this question is to determine if the outcome of the research is considered useful for the particular type of action suggested by the researchers. Most of the articles $(n=17 ; 61 \%)[54,57,59,60,62,65,70-75,77-81]$ explain how the results can be used. For instance, in the work of [59], the authors propose direct action toward energy justice; in a similar fashion, the authors in the work of [54] suggest that their results can be used to help low-carbon communities. Alternatively, in the work of [77], the authors propose enhancing the acceptance of carbon capture and storage infrastructure as a strategy to reduce GHG. Other articles $[73,75,78,79]$ suggest a policy improvement based on their results. Another suggested use is the implementation of the results of other studies on social experimentation and learning situations toward transition [57,62,70]. Lastly, in the work of [60], the authors suggest using extra-academic partnerships to enhance the learning process.

\section{Discussions}

In the course of analyzing the research landscape in our systematic review, we observed an ever-increasing number of articles on learning and environmental sustainability. Despite this, few studies systematically explore these two important issues together in a literature review or evaluation. Therefore, the results of our review help to provide new insights and a degree of continuity with the studies of Gerlak et al. [28], who aimed to fill the gap that had been identified by the intuitions of these researchers. Below, we summarize the results, tracing conceptual links aimed at explaining the research questions on the theoretical and methodological development of studies on learning, dimensions compatible with a cultural approach, and depoliticized agency. Due to the variance in the disciplinary backgrounds of the articles, we chose a narrative synthesis of the results.

\subsection{The Methodological Development of Studies on Learning}

As revealed by the responses to our first research question relating to the theoreti$\mathrm{cal} /$ methodological status of studies involving learning, the literature needs to adapt the theoretical design of the research to what has been put into practice and subsequently found in the study itself. Indeed, according to our first criterion of analysis, we noticed a discrepancy between theoretical and practical levels resulting from a lack of clarity in the literature between different elements that we identified, with some categories of questions presented in the results section. To describe the "theoretical level", the reference elements that we considered are the questions relating to the theoretical approach used in the article (Q1), to the definition of learning (Q3), and, finally, to the research objectives or questions that the examined articles present; to describe the "practical level", we used the question relating to the use of explicitly stated results (Q18). Therefore, to assess these two levels, we examined the degree of clarity of the articles through a dichotomous "explicit/non-explicit" division, thus forming four areas of analysis.

In the first area, we observed that few articles explicitly specify the theoretical and practical levels. As we analyze in the results section, both the definition of learning and the use of the results are explicit in 39\% of the articles. Hypothetically, all articles should have this degree of clarity because, in most cases, a well-explained theoretical foundation ensures clear results and, consequently, enables the use of these results. As Goertz [82] stated, theoretical development in the social sciences starts with explicit attention to the definitions and conceptualization of the key phenomenon of interest.

The opposite area is where neither the theoretical nor the practical level is explicit. In this case, this lack of clarity in the definition of learning (Q3) and of aims or research questions (Q4) has the consequence of preventing the explicit use of the results (Q18). In particular, articles in this area show that when there is a lack of precision in the definition of the theoretical elements, the reference to "learning" is divided into several other theories 
on "learning", leaving these equally vague and imprecise. The results of these articles, therefore, refer to the context of the research without an explicit recommendation for subsequent research.

In the area comprising an explicit theoretical level and a non-explicit practical level, the use of results remains implicit despite an accurate definition of learning, research objectives, and theoretical approach. In one of the articles, we observed that the theoretical approach of "situated learning" is clear, as the scholars cited Lave and Wenger's precise definition of this approach. The purpose of the article is also explicit: to increase understanding of the learning processes in a given context. However, the use of the results is not explicit, as these, as stated by Gerlak et al. [28], are unique "constructions" developed to reflect a particular context. This reflects the emic research perspective of this article and an approach aimed at enhancing a given context. Therefore, an explicit theoretical approach leads to the promotion of behaviors or practices aimed at creating strategies that, as in this case, cannot be generalized.

In the area where the theoretical level is not explicit while the practical one is, we found only one article. This is perhaps the most unusual case among those examined because the use of the results is explicit, while the objectives of the research and the definition of learning are not. We are not sure that this article can be considered scientific, and therefore, we have many doubts about its validity.

The second criterion of analysis for this section involved assessing how explicitly the authors define learning and its object of study in the articles examined in our systematic review. For this purpose, we relate the results of the section dedicated to this criterion in this paper to Q3 and Q7 and the possible effects: change (Q15), the emancipation of the actors involved in the analyzed papers (Q17), and, finally, power (Q18). As we noted in the results section, change is the most frequently stated effect of learning, with $75 \%$ of articles showing this outcome. The other two aforementioned effects are addressed in a much lower percentage of articles. This suggests that change is the effect most desired and achieved by authors addressing the topic of learning. The relationship between the definition of learning and its object also produced a dichotomous "explicit/non-explicit" division in this criterion; this allowed us to observe how the effect of change develops in the various systematically reviewed articles, thus forming four areas of analysis in this case, as well.

In the area in which learning objects and learning definitions are both explicit, learning tends to promote a change in the culture and context in which the study was carried out. This is exemplified in the same previously cited study that referenced Lave and Wenger's precise definition. A clear object and clear definition of learning also promote knowledge regarding other effects, such as power.

In the area where neither the definition nor the object of learning is explicit, the change mentioned by the authors also lacks a clear description. The articles in this area have this characteristic, in which the non-explicit definition of learning is covered only by a reference to "social learning" without providing a rigorous definition. These articles refer to a change, but the lack of the object of learning makes it difficult for readers to share and understand "what" has been changed through learning.

If the object of learning is explicit while its definition is not, the purported change is not clear. In many articles, the definition of learning is not clear and shows the same characteristic as the previous area. Because of the lack of a definition of learning, however, it is unclear "how" change occurs, and thus, there is no distinct way to produce similar triggers that can help to initiate new processes in other contexts that may have similar characteristics.

Finally, the conceptual articles that we found are in the area where there is an explicit definition of learning and a non-explicit definition of the object of learning. By conceptual articles, we mean a document in which theoretical reflections, comments, and speculations are included. Therefore, this is the only area in which it is not possible to have effects 
such as change, power, or emancipation of actors, as the research does not consider the opportunity for an intervention in the target context.

\subsection{Learning Outside the Scope of Transition Theory}

In a recent conceptual review on learning in sustainability transition, van Mierlo and Beers [27] assessed the theoretical possibility of four main learning research programs (social learning in natural resource management, collaborative learning, organizational learning, and interactive learning in the learning economy) to fill the current gaps in sustainability transition studies on the learning process. They provide a conceptual clarification of the role that these learning research programs can play in the core of the transition context (the niche-regime relations), identifying two common elements that characterize the general understanding of learning in transition, namely, reflective action and discursive interaction. The first element refers to an iterative process involving planning, evaluation, and the material condition of problem solving; the second element refers to the socio-cognitive meaning-making process of exchanging knowledge through dialogue. These two elements co-evolve toward a common direction of regime change.

Our results indicate that in the period between 2015 and 2020, studies on learning in transition studies reflect these tenets. For instance, Hoppe et al. [65] use the strategic niche management (SNM) framework to assess the best practice of two local grassroots lowcarbon transition cases. In this case, the learning process is treated as an inherent process of experimentation in the niche context that is necessary to produce a regime change, composed of two recursive actions, the reflective one and the discursive one, each aimed at finding common ground between populations and policy makers. In the other articles that use the SNM framework [66,71], learning is still closely related to experimentation in the local context, and social learning's single-loop/double-loop differentiation is used for the problem-solving process. Similarly, articles that use the transition management framework $[68,73]$ broadly refer to the necessity of social learning for niche experimentation goals. For instance, Sharp and Salter [70] argue that the learning process is a crucial driver that engages participants of local realities (both policy makers and citizens) in order to enhance their low-carbon living and develop an agenda setting. The most cited learning approaches in these studies are social learning and learning-by-doing as a means to link the social dimension with the technological or material dimension. However, the decarbonization endeavor does not end with the use of a specific transition-related theory. Indeed, the majority of articles in this review (68\%) do not refer to a transition theory, even though the main aims are similar (decarbonization and learning process). Besides the explanatory ability and feasibility of the multi-layer transition framework, the issues identified by van Mierlo and Beers [27] as the next step toward theory integration, namely, the situated and relational learning approach, are well-known outside the research tradition of transition studies. For instance, research traditions that use theories such as social movement learning [56,63] and communities of practice [58], if related to the decarbonization context, are moving toward the same scope of SNM, TM, or MLP, but without the niche-regime-driven approach. In this way, the central tenet of learning in the situated context and the range of social levels are not the content of a black box but are the evidence from which a novel transition theory based on participatory epistemologies can be realized [38]. The way to view energy transition is not limited to a niche-regime change approach $[10,11,24]$, and theorizing about learning should not solely follow this path. The risk is two-fold: other theoretical possibilities emerging from empirical knowledge outside the normative research design of socio-technical theories may be neglected, and a unique pathway to search for solutions may be overlooked.

\subsection{Considerations of the Psycho-Cultural Approach in Studies}

For this section, "background" articles with only empirical research were considered, and, among these, those with case studies are emphasized to stress the importance of the context. Empirical articles represent $86 \%$ of the articles studied (24 out of 28 ). Case studies 
represent $75 \%(18 / 24)$ of the 24 empirical studies. Among these 18, 5 are identified as having etic knowledge (28\%), while the remaining 13 have emic knowledge $(72 \%)$, a form of knowledge that, according to Pike [83], is built through the adoption of the distinctions and categories that emerge from the practices of the social actors involved in the research, instead of imposing categories predetermined by the researcher, as in etic research. Given these data, we hypothesized that there was a relationship between the presence of cultural elements within the articles considered and the type of research. Therefore, for this research question, we also categorized the available elements through a $2 \times 2$ factorial design, in which we explore the type of research (emic or etic) with the presence or absence of cultural elements within the analyzed articles. As regards the cultural elements, the categories of questions concerning an explicit reference to cultural elements (Q8), the use of artifacts or material elements of mediation (Q10), and the components linked to irrational or symbolic factors were developed (Q12). To consider the effects of agency, questions are posed on the possible effects of learning, such as change (Q15), emancipation of the actors involved (Q17), and power relations (Q18), and on the uses of the results (Q19).

In the area of the factorial design that we identified as emic research with the presence of cultural elements, agency, defined as "the state of being active, usually in the service of a goal, or of having the power and capability to produce an effect or exert influence" [84], is clearly and precisely defined.

In the area of the factorial design that we identified as etic research with the presence of cultural elements, the tendency of the researchers is to describe, in terms of agency, the effects obtained, while the inherent aspect of the use of the results is unclear or even absent.

In the third area, which we identified as emic research with the absence or low presence of cultural elements, agency reflects what can be achieved with the research, but not the modalities in which the purpose can be realized. The effects of the analysis in the studied context and for the given social actors are not described, providing no explanation for the ways in which learning (in this case, social learning) can be useful to achieve effects, such as a change, in similar situations.

In the last area of the factorial design, which we identified as etic research with the absence or low presence of cultural elements, the research may include agency. These papers represent the standard of research in the social sciences and pursue goals and results starting from a defined theoretical perspective that allows the researcher to observe phenomena and collect data according to that particular conceptual framework.

With regard to the effects on the results and their possible use, the articles that are included in the areas having both emic research with the presence of explicit cultural elements and etic research with the low presence or absence of explicit non-cultural elements are those that present more explicit effects and uses of the results among the articles analyzed, while the articles presenting etic-culture and emic-non-culture configurations are those that have gaps in terms of an explanation of the effects obtained or the potential future use of the results.

\subsection{Negative Facilitators and Positive Barriers}

The concept of culture in the transition literature was studied as a variable that could be useful to accelerate or slow down the process of transition. As Sovacool and Griffith [51] point out, cultural elements such as societal practice, beliefs, and behavioral routines are ways to study barriers to low-carbon technology acceptance and to energy consumption. However, as they state, culture can also be a "catalyst of change" insofar as it can raise awareness of new technology and pro-environmental behavior. As we see in Q7, a large number of articles state the object of learning as an awareness-raising process. Following Sovacool and Griffith [51], we can view the learning process as one way to catalyze the transition process. In order to better refine future transition studies, they further propose considering culture as a constitutive element rather than a mere secondary object. As seen in Q8, only $57 \%$ of the reviewed articles consider at least one cultural element in their design. 
In this context, and in a cultural approach, facilitators and barriers become ways to manifest the intertwining relations between culture and learning: the boundary between them is set by the researchers with their theoretical assumptions. Although the literature mostly regards culture as a barrier [51], our results show that learning is mostly studied with a focus on facilitators and drivers. The learning process is thus viewed as a general positive enhancement process. A clear distinction is made between facilitators as triggers of a new process and facilitators as mediators of a previously started process. For example, Andreotta [64] uses a precise definition of social learning and treats the cultural specificity of Cadore's place as an imaginative trigger of novel possible futures. Similarly, as a learning facilitator, Pacheco et al. [60] describe the triggering effect of engineering students engaging with firms outside the academic context.

As a mediator, Groulx et al. [67] focus on the dialogue between scientists and nonexperts, viewing the learning process itself as a facilitator in order to enhance citizen science. In this way, they consider the psycho-cultural process in terms of its complexity, operationalizing citizen science as a co-constructor of knowledge and enhancer of individual agency. In a similar vein, Larri and Whitehead [59] consider the practice of activism to be an enhancer of learning and cultural transmission within the particular situation of protest, taking into account the multi-level struggle of activists between the psychological, the collective, the place, and the institutional level. Other articles that use a situated approach $[56,58,63]$ have assessed and affirmed the complexity of cultural transmission through the learning process. Despite the general focus on learning as a positive process, there is a notable lack of studies on barriers to learning or, reversing the relation, on learning as a barrier because it excludes one of the ways in which cultural specificity could emerge in a situated context.

Another blind spot identified from our review is the lack of studies on the subconscious level in relation to learning. Only one article mentions the role that bounded rationality can have in the learning process and its potential to act as a barrier [78]. As highlighted in the literature on bounded rationality (cfr. for instance, the classics Thaler and Sunstein [85] and Gigerenzer [86]), the design of the context in which the choice takes place could work as a silent facilitator toward the desired outcome. The context of choice ranges from the remodulation of the environment to the design of mobile devices, which is one of the core policy applications of transition studies. In a psycho-cultural approach, the environment and artifact are not separated from the constitution of the mind. From this point of view, we can refer to Nawi et al. [61]: in their article, they show the potentiality of mobile devices in formal pedagogical contexts such as schools, simultaneously taking into account the cultural, technological, and human dimensions. However, despite the complexity of the multi-dimensional learning process, they followed a research trend that views the interaction between humans and technology as passive, where technology is an object used by humans and not an artifact that actively shapes the cognitive process of the users. In fact, none of the studies in this review attempted to assess the reverse process of learning from context, environment, and devices with an a priori structured design and observe outcomes in cultural practice and beliefs.

\subsection{The Value of Agency}

In a psycho-cultural approach, the roles of context and its cultural manifestation are not disentangled by actors that actively engage that space with their actions. In this regard, but from a different approach, a recent review by Goyal and Howlett [29] points out an implicit assumption in the learning literature: the learning process is assumed to take place in a sequential manner, with no differentiation between actors, the object of learning and the network to which they belong. Instead, they connect specific objects of learning with specific actors' networks, arguing for a parallel function of different learning processes. In brief, they reappraise the value of agency in the situated context of interaction and cultural specificity; indeed, they highlight the need to connect collective and individual levels of learning in order to better understand transition pathways. For the purpose of this 
review, we take the reappraisal for granted and focus on this last point. Agency, namely, the capacities of actors to act and the influence on those capacities [87], is one of the crucial themes in which the socio-technical approaches intersect with their theorization [20]. As a recent review of Bogel and Upham highlights [12], in transition research, the focus on collective agency is prominent, and individual agency, although less present, is the subject of studies guided by a mainstream cognitive psychology approach and theories. Our review confirms this trend, as Q13 reveals a preference for separately analyzing societal and individual levels. Nevertheless, there are articles, although few, that refer to explicit psychosocial agency $[55,56,58,59,63]$ : the ones that use a situated approach to learning enable the realization of this vision. For instance, Ollis [63] studied the informal learning that emerges from activism actions, taking into account the element of the context and its crucial role in knowledge generation and the negotiation of identities. As he points out, contexts of protest are a great equalizer because, in marches, everyone heads toward a unique collectively shared goal, but the cultural specificities of individuals, such as class, disability, age, or ethnicity, are still present, and they have to be taken into account by the protester in order to maintain group cohesion. These precise contexts permit them to explore diversities without the silent reflection of the hegemonic patriarchal and racist status quo. Through a dialogical learning process in which the asymmetrical distinction between learner and teacher is neutralized, knowledge is shared for the sake of the common good and genuine solidarity. The focus on psychosocial agency permits researchers to explore social phenomena without referring to a connection between the individual and the collective because they are recognized as inherently belonging to each other. The nature of actors taken into account is another important element in the evaluation of agency: as we see in Q15, actors range from expert to non-expert due to the specificity of the topic of this review. It can be organized symmetrically, as we have seen in the work of $[63,67]$, or hierarchically, in which the teacher fills the void of the learner with his or her notions. For example, De Bruin et al. [77] designed their study in this way: a set of brochures describing their beliefs about sustainability technologies were shared and distributed to non-experts. This type of research design is the perfect example of an epistemological fallacy, in which the researchers believe that individual learning should translate to a social change without further exploration or at least problematization. Another way to assess actors is to explore the way in which they reflect the value of the place: distinguishing between value extractors (policy makers, entrepreneurs, government or private institution) and value enhancers (activists, prosumers, NGO) can reveal the direction of change that is suggested by the articles. The dimension of change is inherent in both transition [4] and learning [41] conceptualization. Thus, even if it is not explicitly stated, it is implied in the study design, as we see in Q14.

\subsection{The Risk of Depoliticized Agency in Learning}

The agency issues that arise here become political problems since the capacity to act becomes driven and exploited by actors in positions of power, as determined by structural power relations. In governance and policy studies, this theme is studied under the dynamics of politicization/depoliticization: a process that refers to the range of participation, conscientization, and deliberation possibilities of the individual in private and public arenas. Depoliticization is being studied as the neoliberal form of economic governance of the last 30 years, characterized by the privatization of common goods and delegation of political capacity to extra-governmental agencies [88]. Scholars [20,89] distinguish between at least two strategies: societal depoliticization (the role of media, lobbyists, groups of advocacy interest, etc., in removing an item from the agenda of public deliberations) and discursive depoliticization (the rhetorical device and speech activities that tend to naturalize and normalize a particular issue). Beverige and Nauman [90] define the dynamics between depoliticization and politicization as "the movements of issues between an arena of fate and necessity (the non-political), where nothing can be done (depoliticization), to one of deliberation and contingency (the political), where action and change are possible 
(politicization)" (p. 278). A growing corpus of literature operationalizes depoliticization from a psychosocial view [91], in an environmental context [90,92-94], and in the learning process $[95,96]$. In a similar scope but from a different theoretical framework, Smerecnik and Renegar [97] provide one example of the functional use of agency by a specific rhetorical marketing strategy in an environmental context. They refer to this strategy as capitalistic agency: "the capacity to enact, or process of enacting, capitalistic ends and the inherent constraining of agency that is not oriented toward the production of capital" (p. 156). The resonance between depoliticization and capitalistic agency can be seen in the results of these rhetorical practices: the possibility of constraining agency and the hindering of environmental change. Following this literature in the context of our review, we refer to depoliticization as the general concealment of the political value of a certain discourse, process, or object in the learning process regarding decarbonization.

Drawing from our results, we can assess the general lack of emancipation (Q16) and power relation (Q17)-related issues as a depoliticized trend in this research topic. If we take a closer look at this depoliticized trend, we can see that it acts in different ways. Two articles $[70,76]$ refer to the participation of actors considered in the analysis, but they do not consider any associated power relation elements. Despite the notable grounded and emic perspective [70] and the psychosocial elements that link behavior to social change [76], these articles overlook engagement with the societal and institutional levels. In this way, they uniformize the participants in a set of variables useful for policy makers to set up new governance strategies. In fact, not referring to power relations when making engagement arguments conceals the political stance of the transition, leaving the ultimate decision not to the participant but to the elite that possesses the power $[15,23]$. Pacheco et al. [60] argue for a strategy that can enhance learning possibilities for undergraduate engineering students, namely, partnership with extra-academic private and public institutions. As stated by the authors, in this way, students develop the necessary competencies to solve problems in a real-life usage context of energy sources: "Partnership between university and private and public institutions has boosted a set of profits for all the memberships. University students can improve active learning methods by understanding, and developing applied solutions to real problems while university professors increase the knowledge of the local needs through collaboration with the local institutions" [60] (p. 400). Nevertheless, besides the virtuous relationships that can arise, some problems hide beneath the surface. As Cech and Sherick [95] point out, engineering education encompasses a set of issues that are easily predisposed to what they called the ideology of depoliticization: "the belief that engineering is a purely 'technical' space and political and cultural concerns can-and should - be removed from that space" [95] (p. 204). While Pacheco et al. [60] address a way to contextualize the learning process in a real-life context, the real is regarded only as technical knowledge, implying the necessity of the institution. In this way, the broader goal of learning is disentangled by political and cultural elements that are driving the purpose of the institution and remain hidden behind the assumed neutrality of technological design. The change derived from the learning process is a mere adaptation to a wellestablished direction of technological innovation. Culture, as a set of beliefs and practices, is crucial for education in a professional context because it determines the epistemological understanding of the problem design and the role of the professional within society [95]. A similar case that involves culture in a professional context is portrayed by Bratton [69]. As he argues, the role of leaders as change agents is crucial in setting up a pro-environmental management system through the promotion of the low-carbon behavior of their employees. Firstly, the identification of leaders as agents of change suppresses the active role (agency) of employees in the delegation of political power to a paternalistic figure who possesses the knowledge. Secondly, even here, the change required by learning is perceived as a mere adaptation to organizational culture as a set of practices (low-carbon behavior) and beliefs (pro-environmental management). This does not mean that this culture is a bad thing in itself. The problematic point is that the learning process of organizational culture is not contextualized in its natural environment, namely, the capitalist economic system, 
which sees its prerogative as maintaining the power relation in order to gain profit [17]. The way in which low-carbon behavior changes are designed primarily reflects these ends rather than the issues of emancipation or power relations. This depoliticized sustainability narrative of organizational culture determines a capitalistic agency that leads toward a commodified subjectivity and undermines the real effectiveness of the decarbonization aim $[93,97]$. Bruine De Bruin et al. [77] offer another example of depoliticization in the learning process regarding the concealment of ideological underpinnings or the political and social implications of a particular low-carbon innovative technology (in this case, the carbon capture and storage technology) under the rhetoric of the neutrality of technology. Their aim, again, is not directed toward emancipative possibility but toward the desired learning output, which is useful for the application of top-down governance policy. Even in this case, the power relation between the teacher and the learner is reproduced and covered up, resulting in depoliticized agency. However, opposition to this trend exists and is not even very rare: for instance, Mychajluk [58] assessed the unequal distribution of power as a structural barrier to collective participation in sustainable activity. Upham et al. [68] assessed the possibility of participation and engagement of public opinion in governance strategies using a transition management framework; in this way, they prevent the possible blind spot of the theory from being used in a depoliticized way. Ollis $[56,63]$ refers to the theoretical tradition of learning and states that it can be traced back to Freire's pedagogical approach, in which the learning process is primarily seen as a form of liberation and conscientization of agency [98]. Larri and Whitehead [59] take the emancipative possibilities for their (senior women) participants seriously, challenging the hegemonic cultural narrative (mostly occidental) that views the aging process as a process of decay, and so older people, especially women, are regarded as the waste of society due to their lack of usefulness [99].

These are a few examples of how agency is not necessarily tied to a predetermined set of functions, such as depoliticized ones. Therefore, it is necessary to adopt a grounded epistemological approach to grasp the full explanatory potential of the situation. The problem with the capitalistic agency and the depoliticization of learning resides in the commodification of subjectivity, which can hinder the efficacy of the claims about sustainability transition.

\section{Conclusions}

Through a systematic review, this article assesses the state of the literature and its psychosocial and cultural uses in studies concerning learning in the decarbonization context. In particular, we focus on learning as a useful construct for delineating and triggering voluntary and involuntary processes of change in a socio-ecological system. Our review indicates that there are several positive trends in the literature. Although our sample was small, our review draws attention to the growing number of articles in the literature that present the construct of learning in its various forms as an interesting element in support of the theme of environmental sustainability. Similarly, numerous publishers and affiliations address this topic in the context of learning, and this could be an indicator of how the learning process in environmental issues has become increasingly central over the years. Guided by the research questions, we attempted to delineate the existing trend in the literature while assessing the various gaps pointed out by previous scholars. The first question draws from Gerlak et al. [28] and van Mierlo et al. [26], who pointed out the general lack of theoretical and methodological accord in the learning literature; the second question draws from the results of van Mierlo et al. [26], who call for a relational and situated approach to learning. In this context, we apply our cultural psychological approach to this review as an epistemological point of view to offer a critical stance on the learning process [32]. The third question draws from Bogel and Upham's [12,14] insights on the absence of psychosocial agency in socio-technical transition research and from the growing literature on the lack of assessment of power issues in the transition literature, as highlighted by Sovacool and Brisbois [23] and Burke [15]. Due to the great variance in 
theoretical and disciplinary approaches, we relied on a narrative synthesis of the results in order to critically assess the specificity of the single-case article in the relevant literature. Thus, we overcome the problem of external validity by showing the dynamics of single cases and the way in which they can be reproduced. In this way, we searched for relevant qualitative clusters and patterns into which the articles could be organized.

Summarizing the answers to the first question, we found that the theoretical and methodological foundations and developments are limited to fragmentary and implicit descriptions or, in some cases, are even absent. The reference to scientific terminology must refer to explicit definitions and learning objects in the most precise and rigorous way. As we noted earlier in this article, this is to fill the gap, to the greatest extent possible, between what is used by the authors as a theoretical framework and for research purposes and what is actually realized in practical terms. The smaller the difference between these two aspects, the clearer the research, including in terms of the effects obtained and the results achieved. This will help various researchers and scholars to reduce possible misunderstandings, thus creating usable literature for further developments in different contexts and with different social actors involved. We further analyzed the commitment of the sustainability transition literature to the learning process, identifying a theoretical guidance problem that could hinder the human dimension of learning in favor of the development of transition itself.

For the second question, we observed that the empirical applications were limited to describing the research objects achieved through learning in its various forms of research practices, omitting the modalities used in the various contexts and with the different stakeholders involved in the research, especially in the case studies. We know how difficult it is to generalize these emic studies to other research; however, we believe that this description of modalities is useful to indicate which processes overlap between two articles that present similar research situations to evaluate their limits and opportunities and possibly make a comparison aimed at systematically researching and improving the methods used. From a critical stance, we examined the use of facilitators and barriers in the learning context, highlighting the dual effects of shaping the human dimension that can be fostered by learning through the use of artifacts as material cultural elements, bounded rationality, and the modification of the learning environment.

For the third question, we found that the agency attributed to actors in the learning context is generally divided into individual and collective instances, leaving little space for psychosocial agency. In the last section, we critically assess the depoliticization risks that an article on learning and the decarbonization context could encounter. We found an example of depoliticized research on learning but also some that overcome and assess the political value of agency. We argue that depoliticization could occur either on a theoretical and methodological level or in a vicious use of agency. To provide an overall overview of the results, we present Table A4, in which we compile the types of learning, the relevant actor in learning, and the objects of learning taken into account.

A limitation that could have biased the general conclusion is related to the contents of the articles excluded with the exclusion criteria. The choice was made in accordance with the human dimension that we were exploring. However, as an iterative instance with the second research question, we have to point out that a deeper understanding of the learning process goes through an even wider conception of the relation between technology and humans as a reciprocal process of co-construction. To overcome these limiting biases, we call for an interdisciplinary endeavor that can cover a wider range of knowledge than that in this review, and that is able to assess, for example, the role of machine and deep learning and industrial learning in framing the human mind.

One of the gaps in the literature that we can delineate from this study is related to change: learning is one of the many constructs that promote this process and presupposes "working on" a context for a specific situation and social actors at both a cognitive and behavioral level. Gerlak et al. [28] refer to learning from a governance perspective on environmental policies to effect change in the study context in a top-down process. Our proposal is to trigger bottom-up processes aimed in the direction of change through what 
sustains and shapes public engagement with climate change and grassroots involvement in sustainability. Therefore, we concur with Biddau's et al. [35] proposal to analyze the representational change of the social actors involved in a specific research context in order to "work with" the social partners involved in achieving the goal of changing the knowledge of a community, underlining "what role the socio-psychological aspects in interactions, communication and mutual trust between local actors" [35].

In this context of the depoliticization of agency in the learning process, a critical role is played at a theoretical level. As Feola [17] pointed out, there exists a "theoretical bias" in sustainability transition research (STR), as we noted in several points of this article. It consists in considering socio-technical transitions that are actually built within the dynamics of the capitalist economic system, but a critical assessment of capitalism itself is lacking. In order to overcome this theoretical bias, we recommend taking into account emerging grassroots knowledge, practices, and ways to enact agency that are not known by researchers, not only as an epistemological stance but also as a political stance. The potential for actors to be the agents of change requires the liberation of theoretical and social constraints that frame the capacity to act within the environment. The neutrality by which the transition processes are often described, together with technological efficacy, puts the development of subjectivity onto a preset commodified track, detaching it from some possible intervention toward societal change and focusing on responsibilization at the behavioral level, perceived as a consumer and not as a citizen. The use of learning in this context favors the amplification and reification of the depoliticization process, covering the political struggle with a naturalized (or even numinous) veil.

One of the side effects to be aware of is the backlash effect of learning in an asymmetrical relation and in a depoliticized context, that is, the effects of learning by researchers themselves: in this process, what the researchers learn is what is taken for granted by scientific depoliticized rhetoric, such as the application of a neutral methodology, which would automatically help to solve the societal problem by adding a brick of knowledge to the wall of science. In this regard, we agree with Feola [17] when he calls for researchers to reflect on their role in society as producers of a legitimized form of scientific knowledge.

For future research on these themes, we suggest several aspects. First, at the theoretical level, we recommend finding definitions of learning that are already present in the literature by other authors or that refer to a precise theoretical framework because this can serve as a point of reference not only for those conducting the research but also for those reading the article. The hope is to find this in future articles that may have a definition and a precise learning object because this can enable scholars to describe the ways and therefore the processes with which certain effects have been achieved, such as a change in the context and with specific social actors. For transition scholars, we suggest: starting with a critical stance on the research design, following the multiple articles that question the tenets of the various theories in this context (for instance, the work of $[6,10,11,17]$ ), and engaging with disciplinary and epistemological perspectives different from their own in order to foster theoretical creativity and to neutralize the normativity of transition theories. To non-transition scholars, we recommend taking into account the ways in which transition theories, mostly MLP, are connecting different levels of explanations in order to provide a heuristic example of connections between different planes. We also recommend engaging with psychosocial agency in the design of research in order to explore a more detailed dimension of possible changes in the learning process. Similarly, it could be useful to take into account implicit assumptions that involve the learning process, starting from the assessment of power relations and emancipative claims of agency, in order to design research and to produce knowledge that really moves toward a decarbonization aim.

We propose some questions that address the ways in which socio-technical processes are triggered: what are the other constructs that produce changes in the context of decarbonization and sustainability? How are the processes that produce these changes triggered? Is there a systematic way of exploring the production of these effects? How are the di- 
chotomies of human/technology used and exploited? These are all questions that could be useful for those who aim to emphasize the effect of agents of change.

Author Contributions: Conceptualization, N.S., F.G. and P.F.C.; methodology, N.S. and F.G.; formal analysis, N.S., F.G., P.F.C. and F.B.; writing —original draft preparation, N.S., F.G. and P.F.C.; writingreview and editing, N.S., F.G., P.F.C. and F.B.; supervision, P.F.C. and F.B.; project administration, P.F.C. and F.B.; funding acquisition, P.F.C. All authors have read and agreed to the published version of the manuscript.

Funding: We acknowledge the support from the European Union's Horizon 2020 research and innovation programme under grant agreement No 884565 for the TIPPING.plus project (Enabling Positive Tipping Points towards clean-energy transitions in Coal and Carbon Intensive Regions). The sole responsibility for the content of this article lies with the authors.

Institutional Review Board Statement: Not applicable.

Informed Consent Statement: Not applicable.

Conflicts of Interest: The authors declare no conflict of interest.

\section{Appendix A}

Table A1. List of articles reviewed.

\begin{tabular}{|c|c|c|c|}
\hline Authors & Title & Journal & Reference \\
\hline $\begin{array}{l}\text { Hoppe T., Graf A., Warbroek } \\
\text { B., Lammers I., Lepping I. }\end{array}$ & $\begin{array}{l}\text { Local governments supporting local energy } \\
\text { initiatives: Lessons from the best practices of } \\
\text { Saerbeck (Germany) and Lochem (The Netherlands) }\end{array}$ & $\begin{array}{l}\text { Sustainability } \\
\text { (Switzerland) }\end{array}$ & [65] \\
\hline $\begin{array}{l}\text { Lan J., Ma Y., Zhu D., } \\
\text { Mangalagiu D., Thornton T.F. }\end{array}$ & $\begin{array}{c}\text { Enabling value co-creation in the sharing economy: } \\
\text { The case of mobike }\end{array}$ & $\begin{array}{l}\text { Sustainability } \\
\text { (Switzerland) }\end{array}$ & [81] \\
\hline $\begin{array}{l}\text { Heiskanen E., Jalas M., } \\
\text { Rinkinen J., Tainio P }\end{array}$ & $\begin{array}{c}\text { The local community as a "low-carbon lab": } \\
\text { Promises and perils }\end{array}$ & $\begin{array}{l}\text { Environmental } \\
\text { Innovation and } \\
\text { Societal Transitions }\end{array}$ & {$[66]$} \\
\hline $\begin{array}{l}\text { Hobson K., Mayne R., } \\
\text { Hamilton J. }\end{array}$ & $\begin{array}{l}\text { Monitoring and evaluating eco-localisation: Lessons } \\
\text { from UK low carbon community groups }\end{array}$ & $\begin{array}{l}\text { Environment and } \\
\text { Planning A }\end{array}$ & {$[54]$} \\
\hline $\begin{array}{l}\text { Groulx M., Fishback L., } \\
\text { Winegardner A }\end{array}$ & $\begin{array}{l}\text { Citizen science and the public nature of climate } \\
\text { action }\end{array}$ & Polar Geography & [67] \\
\hline Kim J.E. & $\begin{array}{l}\text { Fostering behaviour change to encourage } \\
\text { low-carbon food consumption through community } \\
\text { gardens }\end{array}$ & $\begin{array}{l}\text { International } \\
\text { Journal of Urban } \\
\text { Sciences }\end{array}$ & [55] \\
\hline Ollis T., Hamel-Green M. & $\begin{array}{l}\text { Adult education and radical habitus in an } \\
\text { environmental campaign: Learning in the coal seam } \\
\text { gas protests in Australia }\end{array}$ & $\begin{array}{l}\text { Australian Journal } \\
\text { of Adult Learning }\end{array}$ & [56] \\
\hline $\begin{array}{l}\text { Upham P., Virkamäki V., } \\
\text { Kivimaa P., Hildén M., Wadud } \\
\text { Z. }\end{array}$ & $\begin{array}{l}\text { Socio-technical transition governance and public } \\
\text { opinion: The case of passenger transport in Finland }\end{array}$ & $\begin{array}{l}\text { Journal of } \\
\text { Transport } \\
\text { Geography }\end{array}$ & {$[68]$} \\
\hline $\begin{array}{l}\text { Upham P., Klapper R., Carney } \\
\text { S. }\end{array}$ & $\begin{array}{l}\text { Participatory energy scenario development as } \\
\text { dramatic scripting: A structural narrative analysis }\end{array}$ & $\begin{array}{l}\text { Technological } \\
\text { Forecasting and } \\
\text { Social Change }\end{array}$ & {$[62]$} \\
\hline Bratton A. & $\begin{array}{l}\text { The role of talent development in environmentally } \\
\text { sustainable hospitality: A case study of a Scottish } \\
\text { National Health Service conference centre }\end{array}$ & $\begin{array}{l}\text { Worldwide } \\
\text { Hospitality and } \\
\text { Tourism Themes }\end{array}$ & [69] \\
\hline $\begin{array}{l}\text { Bruine De Bruin W., Mayer } \\
\text { L.A., Morgan M.G. }\end{array}$ & $\begin{array}{c}\text { Developing communications about CCS: Three } \\
\text { lessons learned }\end{array}$ & $\begin{array}{l}\text { Journal of Risk } \\
\text { Research }\end{array}$ & [77] \\
\hline Sharp D., Salter R. & $\begin{array}{l}\text { Direct impacts of an urban living lab from the } \\
\text { participants' perspective: Livewell Yarra }\end{array}$ & $\begin{array}{l}\text { Sustainability } \\
\text { (Switzerland) }\end{array}$ & {$[70]$} \\
\hline $\begin{array}{l}\text { Heiskanen E., Hyvönen K., } \\
\text { Laakso S., Laitila P., } \\
\text { Matschoss K., Mikkonen I. }\end{array}$ & $\begin{array}{l}\text { Adoption and use of low-carbon technologies: } \\
\text { Lessons from } 100 \text { finnish pilot studies, field } \\
\text { experiments and demonstrations }\end{array}$ & $\begin{array}{l}\text { Sustainability } \\
\text { (Switzerland) }\end{array}$ & [57] \\
\hline
\end{tabular}


Table A1. Cont.

\begin{tabular}{|c|c|c|c|}
\hline Authors & Title & Journal & Reference \\
\hline $\begin{array}{l}\text { van der Grijp N., van der } \\
\text { Woerd F., Gaiddon B., } \\
\text { Hummelshøj R., Larsson M., } \\
\text { Osunmuyiwa O., Rooth R. }\end{array}$ & $\begin{array}{l}\text { Demonstration projects of Nearly Zero Energy } \\
\text { Buildings: Lessons from end-user experiences in } \\
\text { Amsterdam, Helsingborg, and Lyon }\end{array}$ & $\begin{array}{l}\text { Energy Research } \\
\text { and Social Science }\end{array}$ & {$[71]$} \\
\hline $\begin{array}{l}\text { Alade T., Edelenbos J., Gianoli } \\
\text { A. }\end{array}$ & $\begin{array}{l}\text { Frugality in multi-actor interactions and absorptive } \\
\text { capacity of Addis-Ababa light-rail transport }\end{array}$ & $\begin{array}{l}\text { Journal of Urban } \\
\text { Management }\end{array}$ & [72] \\
\hline $\begin{array}{l}\text { Rosenbloom D., Meadowcroft } \\
\text { J., Sheppard S., Burch S., } \\
\text { Williams S. }\end{array}$ & $\begin{array}{l}\text { Transition experiments: Opening up low-carbon } \\
\text { transition pathways for Canada through innovation } \\
\text { and learning }\end{array}$ & $\begin{array}{l}\text { Canadian Public } \\
\text { Policy }\end{array}$ & [73] \\
\hline $\begin{array}{l}\text { Nikkels M.J., Guillaume } \\
\text { J.H.A., Leith P., Mendham } \\
\text { N.J., van Oel P.R., Hellegers } \\
\text { P.J.G.J., Meinke H. }\end{array}$ & $\begin{array}{c}\text { Participatory crossover analysis to support } \\
\text { discussions about investments in irrigation water } \\
\text { sources }\end{array}$ & $\begin{array}{c}\text { Water } \\
\text { (Switzerland) }\end{array}$ & {$[79]$} \\
\hline Mychajluk L. & $\begin{array}{l}\text { Learning to live and work together in an ecovillage } \\
\text { community of practice }\end{array}$ & $\begin{array}{l}\text { European Journal } \\
\text { for Research on the } \\
\text { Education and } \\
\text { Learning of Adults }\end{array}$ & [58] \\
\hline Hogarth J.R. & $\begin{array}{l}\text { Evolutionary models of sustainable economic } \\
\text { change in Brazil: No-till agriculture, reduced } \\
\text { deforestation and ethanol biofuels }\end{array}$ & $\begin{array}{c}\text { Environmental } \\
\text { Innovation and } \\
\text { Societal Transitions }\end{array}$ & [78] \\
\hline Larri L., Whitehouse H. & $\begin{array}{l}\text { Nannagogy: Social movement learning for older } \\
\text { women's activism in the gas fields of Australia }\end{array}$ & $\begin{array}{l}\text { Australian Journal } \\
\text { of Adult Learning }\end{array}$ & [59] \\
\hline Barazza E., Strachan N. & $\begin{array}{c}\text { The co-evolution of climate policy and investments } \\
\text { in electricity markets: Simulating agent dynamics in } \\
\text { UK, German and Italian electricity sectors }\end{array}$ & $\begin{array}{l}\text { Energy Research } \\
\text { and Social Science }\end{array}$ & [74] \\
\hline $\begin{array}{l}\text { Pacheco L., Ningsu L., Pujol T., } \\
\text { Gonzalez J.R., Ferrer }\end{array}$ & $\begin{array}{c}\text { Impactful engineering education through } \\
\text { sustainable energy collaborations with public and } \\
\text { private entities }\end{array}$ & $\begin{array}{l}\text { International } \\
\text { Journal of } \\
\text { Sustainability in } \\
\text { Higher Education }\end{array}$ & {$[60]$} \\
\hline $\begin{array}{l}\text { Nawi N.D., Phang F.A., } \\
\text { Mohd-Yusof K., Rahman } \\
\text { N.F.A., Zakaria Z.Y., Hassan } \\
\text { S.A.H.B.S., Musa A.N. }\end{array}$ & $\begin{array}{c}\text { Instilling low carbon awareness through } \\
\text { technology-enhanced cooperative problem based } \\
\text { learning }\end{array}$ & $\begin{array}{l}\text { International } \\
\text { Journal of } \\
\text { Emerging } \\
\text { Technologies in } \\
\text { Learning }\end{array}$ & {$[61]$} \\
\hline $\begin{array}{l}\text { Kotilainen K., Aalto P., Valta J., } \\
\text { Rautiainen A., Kojo M., } \\
\text { Sovacool B.K }\end{array}$ & $\begin{array}{c}\text { From path dependence to policy mixes for Nordic } \\
\text { electric mobility: Lessons for accelerating future } \\
\text { transport transitions }\end{array}$ & Policy Sciences & [75] \\
\hline Wiegink N. & $\begin{array}{c}\text { Learning lessons and curbing criticism Legitimizing } \\
\text { involuntary resettlement and extractive projects in } \\
\text { Mozambique: }\end{array}$ & $\begin{array}{l}\text { Political } \\
\text { Geography }\end{array}$ & {$[80]$} \\
\hline Stoll-Kleemann S., O’Riordan & $\begin{array}{l}\text { Revisiting the psychology of denial concerning } \\
\text { low-carbon behaviors: From moral disengagement } \\
\text { to generating social change }\end{array}$ & $\begin{array}{l}\text { Sustainability } \\
\text { (Switzerland) }\end{array}$ & [76] \\
\hline Ollis T.A. & $\begin{array}{l}\text { Adult learning and circumstantial activism in the } \\
\text { coal seam gas protests: Informal and incidental } \\
\text { learning in an environmental justice movement }\end{array}$ & $\begin{array}{l}\text { Studies in the } \\
\text { Education of } \\
\text { Adults }\end{array}$ & {$[63]$} \\
\hline Andreotta $\mathrm{C}$. & $\begin{array}{l}\text { Visioneering futures: A way to boost regional } \\
\text { awareness of the low-carbon future }\end{array}$ & $\begin{array}{l}\text { Regional Studies, } \\
\text { Regional Science }\end{array}$ & {$[64]$} \\
\hline
\end{tabular}




\section{Appendix B. Results Tables}

Table A2. Publication rankings by discipline and nation.

\begin{tabular}{|c|c|c|c|c|c|c|c|c|c|}
\hline \multirow[b]{2}{*}{ Year } & \multicolumn{3}{|c|}{ Social Science } & \multicolumn{3}{|c|}{ Education } & \multicolumn{3}{|c|}{ Geography, Planning and Development } \\
\hline & Ranking & Country & Documents & Ranking & Country & Documents & Ranking & Country & Documents \\
\hline \multirow{10}{*}{2015} & 1 & USA & 68,035 & 1 & USA & 18,008 & 1 & USA & 5716 \\
\hline & 2 & UK & 23,144 & 2 & UK & 4221 & 2 & UK & 3146 \\
\hline & 3 & China & 12,191 & 3 & Australia & 2997 & 3 & China & 2040 \\
\hline & 4 & Australia & 11,455 & 4 & China & 2344 & 4 & Germany & 1627 \\
\hline & 5 & Germany & 10,538 & 5 & Canada & 2324 & 5 & Australia & 1480 \\
\hline & 6 & Canada & 10,250 & 6 & Spain & 2051 & 6 & Canada & 1313 \\
\hline & 7 & Spain & 9143 & 7 & Germany & 1829 & 7 & Italy & 1212 \\
\hline & 8 & France & 8031 & 8 & Brazil & 1460 & 8 & Spain & 1141 \\
\hline & 9 & Italy & 7011 & 9 & Turkey & 1321 & 9 & France & 1053 \\
\hline & 10 & Netherlands & 6090 & 10 & Netherlands & 1074 & 10 & Netherlands & 982 \\
\hline Others & 27 & Finland & 2168 & 22 & Finland & 601 & 25 & Finland & 339 \\
\hline \multirow{11}{*}{2016} & Ranking & Country & Documents & Ranking & Country & Documents & Ranking & Country & Documents \\
\hline & 1 & USA & 70,445 & 1 & USA & 18,822 & 1 & USA & 6182 \\
\hline & 2 & UK & 24,384 & 2 & UK & 4569 & 2 & UK & 3331 \\
\hline & 3 & China & 14,282 & 3 & Australia & 3138 & 3 & China & 3085 \\
\hline & 4 & Australia & 11,939 & 4 & China & 2772 & 4 & Germany & 1825 \\
\hline & 5 & Germany & 11,738 & 5 & Spain & 2422 & 5 & Australia & 1561 \\
\hline & 6 & Canada & 10,698 & 6 & Canada & 2366 & 6 & Spain & 1447 \\
\hline & 7 & Spain & 10,499 & 7 & Germany & 2110 & 7 & Canada & 1440 \\
\hline & 8 & France & 8498 & 8 & $\begin{array}{l}\text { Russian } \\
\text { federation }\end{array}$ & 2047 & 8 & Italy & 1357 \\
\hline & 9 & India & 8093 & 9 & Turkey & 1551 & 9 & France & 1095 \\
\hline & 10 & Italy & 8032 & 10 & Brazil & 1530 & 10 & Netherlands & 1092 \\
\hline \multirow{11}{*}{2017} & Ranking & Country & Documents & Ranking & Country & Documents & Ranking & Country & Documents \\
\hline & 1 & USA & 71,056 & 1 & USA & 18,709 & 1 & USA & 6177 \\
\hline & 2 & UK & 25,107 & 2 & UK & 4456 & 2 & China & 3907 \\
\hline & 3 & China & 14,357 & 3 & Australia & 3271 & 3 & UK & 3415 \\
\hline & 4 & Australia & 12,659 & 4 & China & 2612 & 4 & Germany & 1858 \\
\hline & 5 & Germany & 12,129 & 5 & Canada & 2322 & 5 & Australia & 1790 \\
\hline & 6 & Canada & 10,767 & 6 & Spain & 2237 & 6 & Italy & 1593 \\
\hline & 7 & Spain & 10,714 & 7 & Germany & 1986 & 7 & Canada & 1475 \\
\hline & 8 & Italy & 8896 & 8 & Malaysia & 1924 & 8 & Spain & 1472 \\
\hline & 9 & France & 8431 & 9 & Indonesia & 1569 & 9 & France & 1193 \\
\hline & 10 & India & 8058 & 10 & Brazil & 1560 & 10 & Netherlands & 1154 \\
\hline Other & 30 & Finland & 2168 & 22 & Finland & 601 & 25 & Finland & 339 \\
\hline \multirow{11}{*}{2018} & Ranking & Country & Documents & Ranking & Country & Documents & Ranking & Country & Documents \\
\hline & 1 & USA & 74,249 & 1 & USA & 19,541 & 1 & USA & 6767 \\
\hline & 2 & UK & 26,985 & 2 & UK & 4887 & 2 & China & 5784 \\
\hline & 3 & China & 17,838 & 3 & Australia & 3302 & 3 & UK & 3951 \\
\hline & 4 & Australia & 13,381 & 4 & Spain & 2985 & 4 & Germany & 2194 \\
\hline & 5 & Germany & 12,958 & 5 & China & 2855 & 5 & Spain & 2067 \\
\hline & 6 & Spain & 12,608 & 6 & Brazil & 2440 & 6 & Italy & 2052 \\
\hline & 7 & Canada & 11,295 & 7 & Canada & 2403 & 7 & Australia & 1978 \\
\hline & 8 & Italy & 9968 & 8 & $\begin{array}{c}\text { Russian } \\
\text { Federation }\end{array}$ & 2130 & 8 & Brazil & 1537 \\
\hline & 9 & $\begin{array}{l}\text { Russian } \\
\text { Federation }\end{array}$ & 8384 & 9 & Germany & 2094 & 9 & Canada & 1473 \\
\hline & 10 & France & 8198 & 10 & Turkey & 1698 & 10 & Netherlands & 1363 \\
\hline Other & 35 & Austria & 2209 & 42 & Austria & 296 & 26 & Austria & 495 \\
\hline
\end{tabular}


Table A2. Cont.

\begin{tabular}{|c|c|c|c|c|c|c|c|c|c|}
\hline \multirow[b]{2}{*}{ Year } & \multicolumn{3}{|c|}{ Social Science } & \multicolumn{3}{|c|}{ Education } & \multicolumn{3}{|c|}{ Geography, Planning and Development } \\
\hline & Ranking & Country & Documents & Ranking & Country & Documents & Ranking & Country & Documents \\
\hline \multirow{11}{*}{2019} & Ranking & Country & Documents & Ranking & Country & Documents & Ranking & Country & Documents \\
\hline & 1 & USA & 74,668 & 1 & USA & 21,229 & 1 & USA & 6867 \\
\hline & 2 & UK & 28,009 & 2 & UK & 5469 & 2 & China & 6291 \\
\hline & 3 & China & 22,415 & 3 & China & 3890 & 3 & UK & 4061 \\
\hline & 4 & Australia & 14,263 & 4 & Australia & 3666 & 4 & Spain & 2300 \\
\hline & 5 & Germany & 13,694 & 5 & Germany & 3255 & 5 & Italy & 2244 \\
\hline & 6 & Spain & 13,216 & 6 & Canada & 2679 & 6 & Germany & 2231 \\
\hline & 7 & Canada & 11,874 & 7 & Indonesia & 2588 & 7 & Australia & 2135 \\
\hline & 8 & Italy & 10,159 & 8 & Brazil & 2518 & 8 & Canada & 1640 \\
\hline & 9 & $\begin{array}{c}\text { Russian } \\
\text { Federation }\end{array}$ & 10,076 & 9 & Germany & 2426 & 9 & Netherlands & 1411 \\
\hline & 10 & India & 9224 & 10 & $\begin{array}{c}\text { Russian } \\
\text { Federation }\end{array}$ & 2304 & 10 & South Korea & 1340 \\
\hline \multirow{11}{*}{2020} & Ranking & Country & Documents & Ranking & Country & Documents & Ranking & Country & Documents \\
\hline & 1 & USA & 81,734 & 1 & USA & 22,331 & 1 & USA & 8298 \\
\hline & 2 & UK & 31,974 & 2 & UK & 6215 & 2 & China & 7914 \\
\hline & 3 & China & 26,151 & 3 & China & 4492 & 3 & UK & 5149 \\
\hline & 4 & Spain & 16,172 & 4 & Australia & 4136 & 4 & Spain & 3530 \\
\hline & 5 & Australia & 16,058 & 5 & Spain & 3768 & 5 & Italy & 3087 \\
\hline & 6 & Germany & 15,388 & 6 & Canada & 3048 & 6 & Germany & 2729 \\
\hline & 7 & Canada & 13,624 & 7 & Indonesia & 2867 & 7 & Australia & 2523 \\
\hline & 8 & India & 11,974 & 8 & Germany & 2804 & 8 & Canada & 1998 \\
\hline & 9 & Italy & 11,759 & 9 & Brazil & 2402 & 9 & India & 1901 \\
\hline & 10 & $\begin{array}{c}\text { Russian } \\
\text { Federation }\end{array}$ & 10,414 & 10 & $\begin{array}{c}\text { Russian } \\
\text { Federation }\end{array}$ & 2326 & 10 & Brazil & 1871 \\
\hline
\end{tabular}

Table A3. University affiliation, journal and publisher.

\begin{tabular}{|c|c|c|c|c|c|c|c|c|}
\hline $\mathbf{N}^{\circ}$ & $\begin{array}{c}\text { Year of } \\
\text { Publication }\end{array}$ & $\begin{array}{c}\mathbf{N}^{\circ} \\
\text { Article } \\
\text { per Year }\end{array}$ & $\begin{array}{c}\text { University } \\
\text { Affiliations } \\
\text { Country }\end{array}$ & $\mathbf{N}^{\circ}$ & Journal & $\mathbf{N}^{\circ}$ & Publisher & $\mathbf{N}^{\circ}$ \\
\hline 1 & \multirow{5}{*}{2015} & 1 & UK & 1 & Journal of Risk Research & 1 & Routledge & 1 \\
\hline 2 & & 2 & Australia & 1 & $\begin{array}{l}\text { Australian Journal of } \\
\text { Adult Learning }\end{array}$ & 1 & $\begin{array}{l}\text { Adult Learning } \\
\text { Australia Inc }\end{array}$ & 1 \\
\hline 3 & & 3 & Finland & 1 & $\begin{array}{l}\text { Journal of Transport } \\
\text { Geography }\end{array}$ & 1 & Elsevier & 1 \\
\hline 4 & & 4 & Finland & 2 & $\begin{array}{c}\text { Environmental Innovation } \\
\text { and Societal Transitions }\end{array}$ & 1 & Elsevier & 2 \\
\hline 5 & & 5 & $\begin{array}{l}\text { Netherlands And } \\
\text { Germany }\end{array}$ & $\begin{array}{c}\mathrm{N} \\
(1) \\
\mathrm{G} \\
(1)\end{array}$ & Sustainability & 1 & MDPI & 1 \\
\hline 6 & \multirow{2}{*}{2016} & 1 & UK & 2 & $\begin{array}{l}\text { Technological Forecasting } \\
\text { and Social Change }\end{array}$ & 1 & Elsevier & 3 \\
\hline 7 & & 2 & Germany & 2 & $\begin{array}{c}\text { Environment and } \\
\text { Planning A }\end{array}$ & 1 & $\begin{array}{l}\text { Sage Publications } \\
\text { Ltd. }\end{array}$ & 1 \\
\hline
\end{tabular}


Table A3. Cont.

\begin{tabular}{|c|c|c|c|c|c|c|c|c|}
\hline $\mathbf{N}^{\circ}$ & $\begin{array}{c}\text { Year of } \\
\text { Publication }\end{array}$ & $\begin{array}{c}\mathbf{N}^{\circ} \\
\text { Article } \\
\text { per Year }\end{array}$ & $\begin{array}{c}\text { University } \\
\text { Affiliations } \\
\text { Country }\end{array}$ & $\mathbf{N}^{\circ}$ & Journal & $\mathbf{N}^{\circ}$ & Publisher & $\mathbf{N}^{\circ}$ \\
\hline 8 & \multirow{6}{*}{2017} & 1 & Canada & 1 & $\begin{array}{l}\text { European Journal for } \\
\text { Research on the Education } \\
\text { and Learning of Adults }\end{array}$ & 1 & $\begin{array}{c}\text { Linkoping } \\
\text { University } \\
\text { Electronic Press }\end{array}$ & 1 \\
\hline 9 & & 2 & UK & 3 & $\begin{array}{l}\text { Environmental Innovation } \\
\text { and Societal Transitions }\end{array}$ & 2 & Elsevier & 4 \\
\hline 10 & & 3 & Finland & 3 & Sustainability & 2 & MDPI & 2 \\
\hline 11 & & 4 & Australia & 2 & Sustainability & 3 & MDPI & 3 \\
\hline 12 & & 5 & UK & 4 & $\begin{array}{l}\text { International Journal of } \\
\text { Urban Sciences }\end{array}$ & 1 & Routledge & 2 \\
\hline 13 & & 6 & $\begin{array}{l}\text { China, UK And } \\
\text { France }\end{array}$ & 5 & Sustainability & 4 & MDPI & 4 \\
\hline 14 & \multirow{3}{*}{2018} & 1 & Austria & 1 & $\begin{array}{l}\text { Regional Studies, } \\
\text { Regional Science }\end{array}$ & 1 & Routledge & 3 \\
\hline 15 & & 2 & Canada & 2 & Canadian Public Policy & 1 & $\begin{array}{l}\text { University Of } \\
\text { Toronto Press Inc. }\end{array}$ & 1 \\
\hline 16 & & 3 & UK & 6 & $\begin{array}{l}\text { Worldwide Hospitality } \\
\text { and Tourism Themes }\end{array}$ & 1 & $\begin{array}{l}\text { Emerald Group } \\
\text { Publishing Ltd. }\end{array}$ & 1 \\
\hline 17 & \multirow{8}{*}{2019} & 1 & Malaysia & 1 & $\begin{array}{l}\text { International Journal of } \\
\text { Emerging Technologies in } \\
\text { Learning }\end{array}$ & 1 & $\begin{array}{l}\text { Kassel University } \\
\text { Press Gmbh }\end{array}$ & 1 \\
\hline 18 & & 2 & Spain & 1 & $\begin{array}{c}\text { International Journal of } \\
\text { Sustainability in Higher } \\
\text { Education }\end{array}$ & 1 & $\begin{array}{l}\text { Emerald Group } \\
\text { Publishing Ltd. }\end{array}$ & 2 \\
\hline 19 & & 3 & Finland & 4 & Policy Sciences & 1 & Springer & 1 \\
\hline 20 & & 4 & Netherlands & 2 & $\begin{array}{l}\text { Journal of Urban } \\
\text { Management }\end{array}$ & 1 & Elsevier & 5 \\
\hline 21 & & 5 & Canada & 3 & Polar Geography & 1 & Routledge & 4 \\
\hline 22 & & 6 & Netherlands & 3 & Water (Switzerland) & 1 & MDPI & 5 \\
\hline 23 & & 7 & Australia & 3 & $\begin{array}{l}\text { Australian Journal of } \\
\text { Adult Learning }\end{array}$ & 2 & $\begin{array}{l}\text { Adult Learning } \\
\text { Australia Inc }\end{array}$ & 2 \\
\hline 24 & & 8 & Netherlands & 4 & $\begin{array}{l}\text { Energy Research and } \\
\text { Social Science }\end{array}$ & 1 & Elsevier & 6 \\
\hline 25 & \multirow{4}{*}{2020} & 1 & Australia & 4 & $\begin{array}{c}\text { Studies in the Education } \\
\text { of Adults }\end{array}$ & 1 & Routledge & 5 \\
\hline 26 & & 2 & Germany & 3 & Sustainability & 5 & MDPI & 6 \\
\hline 27 & & 3 & UK & 7 & $\begin{array}{l}\text { Energy Research and } \\
\text { Social Science }\end{array}$ & 1 & Elsevier & 7 \\
\hline 28 & & 4 & Netherlands & 5 & Political Geography & 1 & Elsevier & 8 \\
\hline & Total & 28 & & 28 & & 28 & & 28 \\
\hline
\end{tabular}


Table A4. List of questions with relative answers and related articles.

\begin{tabular}{|c|c|c|c|c|}
\hline ID & Question & Answer & $\mathbf{N}^{\circ}$ (Percentage) & Articles \\
\hline \multirow{3}{*}{1} & \multirow{3}{*}{$\begin{array}{l}\text { What is the theoretical approach used in the } \\
\text { article? }\end{array}$} & $\begin{array}{l}\text { Theories regarding } \\
\text { learning }\end{array}$ & $10(36 \%)$ & [54-63] \\
\hline & & $\begin{array}{c}\text { Theories not } \\
\text { directly related to } \\
\text { learning }\end{array}$ & $13(46 \%)$ & [64-76] \\
\hline & & Unspecified & $5(18 \%)$ & [77-81] \\
\hline \multirow{2}{*}{2} & \multirow{2}{*}{ Is it conceptual or empirical research? } & Conceptual & $4(14 \%)$ & {$[73,75,78,80]$} \\
\hline & & Empirical & $24(86 \%)$ & {$[54-72,74,76,77,79,81]$} \\
\hline \multirow{2}{*}{3} & \multirow{2}{*}{$\begin{array}{l}\text { What is the definition of learning stated in the } \\
\text { article? }\end{array}$} & Explicit & $12(43 \%)$ & $\begin{array}{c}{[55,57,58,61,63-} \\
65,70,71,74,75,80]\end{array}$ \\
\hline & & $\begin{array}{l}\text { Implicit/mentioned/not } \\
\text { found }\end{array}$ & $16(57 \%)$ & $\begin{array}{c}{[54,56,57,59,60,62,66-} \\
69,72,73,76-79,81]\end{array}$ \\
\hline \multirow{3}{*}{4} & \multirow{3}{*}{ What are the aim/scope/research questions? } & $\begin{array}{l}\text { Explicitly refers to } \\
\text { learning }\end{array}$ & $9(32 \%)$ & {$[56-59,61,63,66,71,80]$} \\
\hline & & $\begin{array}{l}\text { Implicitly refers to } \\
\text { learning }\end{array}$ & $8(29 \%)$ & {$[55,62,64,67,69,70,76,81]$} \\
\hline & & $\begin{array}{l}\text { Not linked with } \\
\text { learning }\end{array}$ & $11(39 \%)$ & {$[54,60,65,68,72-75,77-79]$} \\
\hline \multirow[t]{2}{*}{5} & \multirow[t]{2}{*}{ Are there any references to transition theories? } & No & $19(68 \%)$ & $\begin{array}{c}{[55-61,63,64,67,69,71,72,74} \\
76,77,79-81]\end{array}$ \\
\hline & & Yes & $9(32 \%)$ & {$[54,62,65,66,68,70,73,75,78]$} \\
\hline \multirow[t]{2}{*}{6} & \multirow{2}{*}{$\begin{array}{l}\text { Is the kind of knowledge taken into account } \\
\text { emic or etic? }\end{array}$} & Emic & $20(71 \%)$ & $\begin{array}{c}{[54-59,61-68,70-} \\
72,75,76,80]\end{array}$ \\
\hline & & Etic & $8(29 \%)$ & {$[60,69,73,74,77-79,81]$} \\
\hline \multirow[b]{2}{*}{7} & \multirow[b]{2}{*}{ Is the object or scope of learning explicit? } & No & $8(29 \%)$ & {$[54,62,68,72,74,77,79,80]$} \\
\hline & & Yes & $20(71 \%)$ & $\begin{array}{l}{[55-61,63-67,69-} \\
71,73,75,76,78,80]\end{array}$ \\
\hline \multirow{2}{*}{8} & \multirow{2}{*}{$\begin{array}{l}\text { Are there any cultural elements taken into } \\
\text { account? }\end{array}$} & No & $12(43 \%)$ & {$[60,62,68,74-81]$} \\
\hline & & Yes & $16(57 \%)$ & {$[54-59,61,63-67,69-73]$} \\
\hline \multirow{2}{*}{9} & \multirow{2}{*}{$\begin{array}{l}\text { Is the learning process tied to the use of } \\
\text { artifacts or material elements? }\end{array}$} & No & $15(54 \%)$ & $\begin{array}{c}{[54,56,58,62,63,65,66,69,70,} \\
73,74,76,78-80]\end{array}$ \\
\hline & & Yes & $13(46 \%)$ & $\begin{array}{c}{[55,57,59-} \\
61,64,67,68,71,72,75,77,81]\end{array}$ \\
\hline \multirow[b]{2}{*}{10} & \multirow{2}{*}{$\begin{array}{l}\text { Are there any factors that drive or hinder the } \\
\text { learning process? }\end{array}$} & No & $4(14 \%)$ & {$[64,68,73,78]$} \\
\hline & & Yes & $24(86 \%)$ & $\begin{array}{c}{[54-63,65-67,69-72,74-} \\
77,79-81]\end{array}$ \\
\hline \multirow{2}{*}{11} & \multirow{2}{*}{$\begin{array}{l}\text { Is the learning process explicitly related to an } \\
\text { irrational dimension? }\end{array}$} & No & $22(79 \%)$ & {$[55,56,76-79]$} \\
\hline & & Yes & $6(21 \%)$ & {$[54,57-75,80,81]$} \\
\hline
\end{tabular}


Table A4. Cont.

\begin{tabular}{|c|c|c|c|c|}
\hline ID & Question & Answer & $\mathbf{N}^{\circ}$ (Percentage) & Articles \\
\hline \multirow{8}{*}{12} & \multirow{8}{*}{$\begin{array}{l}\text { In which context are the actors taken into } \\
\text { account? }\end{array}$} & $\begin{array}{l}\text { Scholastic and } \\
\text { Educational }\end{array}$ & $2(7 \%)$ & {$[61,67]$} \\
\hline & & Agricultural & $2(7 \%)$ & {$[78,79]$} \\
\hline & & Political & $3(11 \%)$ & {$[65,75,80]$} \\
\hline & & Community & $3(11 \%)$ & {$[54,55,58]$} \\
\hline & & $\begin{array}{l}\text { Industrial and } \\
\text { Organizational }\end{array}$ & $3(11 \%)$ & {$[60,69,74]$} \\
\hline & & $\begin{array}{l}\text { Everyday life, } \\
\text { household, urban, } \\
\text { mobility }\end{array}$ & $9(32 \%)$ & {$[57,62,66,68,70-73,81]$} \\
\hline & & Activism & $3(11 \%)$ & {$[56,59,63]$} \\
\hline & & Not specified & $1(4 \%)$ & [77] \\
\hline \multirow{2}{*}{13} & \multirow{2}{*}{ Who are the actors involved? } & $\begin{array}{l}\text { Expert }<-> \\
\text { Non-expert }\end{array}$ & $8(29 \%)$ & {$[60,61,63,67-69,76,77]$} \\
\hline & & $\begin{array}{l}\text { Value extractor }<-> \\
\text { Value producer }\end{array}$ & $20(71 \%)$ & $\begin{array}{c}{[54-59,62,64-66,70-75,78-} \\
81]\end{array}$ \\
\hline \multirow[b]{2}{*}{14} & \multirow{2}{*}{$\begin{array}{l}\text { Is the learning process referred to as a form of } \\
\text { change? }\end{array}$} & No & $7(25 \%)$ & {$[54,57,60,62,74,77,80]$} \\
\hline & & Yes & $21(75 \%)$ & $\begin{array}{l}{[55,56,58,59,61,63-} \\
73,75,76,78,79,81]\end{array}$ \\
\hline \multirow{5}{*}{15} & \multirow{5}{*}{ Which social level is involved in learning? } & Intrapersonal & $9(32 \%)$ & {$[55,61,63,64,67,69,76,77,79]$} \\
\hline & & Interpersonal & $4(14 \%)$ & {$[56,59,60,67]$} \\
\hline & & Group/Community & $12(43 \%)$ & $\begin{array}{c}{[54-56,58-} \\
61,63,66,69,70,81]\end{array}$ \\
\hline & & Societal & $14(50 \%)$ & $\begin{array}{c}{[57,62,64-66,68,70-} \\
75,78,80,81]\end{array}$ \\
\hline & & Multiple & $10(36 \%)$ & {$[55,56,59-61,63,64,66,67,69]$} \\
\hline \multirow[t]{2}{*}{16} & \multirow{2}{*}{$\begin{array}{l}\text { Is the learning process referred to as a } \\
\text { possibility for emancipation of the actor } \\
\text { involved? }\end{array}$} & No & $19(68 \%)$ & $\begin{array}{l}{[54,55,57,58,60,62,64-} \\
66,69,71,73-75,77-81]\end{array}$ \\
\hline & & Yes & $9(32 \%)$ & {$[56,59,61,63,67,68,70,72,76]$} \\
\hline \multirow[t]{2}{*}{17} & \multirow[t]{2}{*}{$\begin{array}{l}\text { Are there any elements that appear as power } \\
\text { relations within the learning process? }\end{array}$} & No & $19(68 \%)$ & $\begin{array}{c}{[55,57,60-62,64,66,67,69-} \\
\quad 71,73,74,76-81]\end{array}$ \\
\hline & & Yes & $9(32 \%)$ & {$[54,56,58,59,63,65,68,72,75]$} \\
\hline \multirow[b]{2}{*}{18} & \multirow{2}{*}{ Is the use of results explicitly stated? } & No & $11(39 \%)$ & {$[55,56,58,61,63,64,66-69,76]$} \\
\hline & & Yes & $17(61 \%)$ & $\begin{array}{c}{[54,57,59,60,62,65,70-75,77-} \\
81]\end{array}$ \\
\hline
\end{tabular}


Table A5. Overall results.

\begin{tabular}{lll}
\hline Type of Learning (How?) & Actors (Who?) & Object (What?) \\
\hline & & Decarbonization awareness \\
& & {$[56,59]:$ Territorial exploitation due to renewable energy, } \\
& & socially elaborated during protest practice \\
Social learning $[55,65,66,68]$ & Community participants & [61]: Low-carbon information gathering through digital \\
& technologies and classroom discussions \\
& [64]: Low-carbon future imagineries for the territory \\
& [69]: Elaborating and promoting a pro-environmental firm \\
& culture
\end{tabular}

\section{Niche to regime change dynamics}

[65]: Improvement of policy innovations for low-carbon experimentation

Experiential learning $[55,60-62,67,70,80]$ Activists $[56,59,63]$ Situated learning [54,56-58,63]

Policymakers $[57,64-66,74,75,78-80]$
[66]: Citizen representation of urban low-carbon experimentation

[70]: Low-carbon urban development as community development

[71]: Low-carbon policy for efficiency of buildings

[78]: Economic development and territorial governance

\section{New knowledge production}

[57]: Low-carbon technology usage

[58]: Co-construction of cooperative culture

[60]: Renewable energy project development

[63]: Social movement practice for societal change in face of territorial exploitation

[67]: Appropriation and adoption of scientific means by citizens contributing to science

\section{Cognitive and behavioral change}

[55]: Reducing food-related carbon footprint through pro-environmental food consumption behavior

Cognitive learning $[57,76] \quad$ Students $[60,61]$ [75]: Policy improvement for urban electric vehicle mobility [76]: Overcoming moral disengagement related to high-carbon behavior

[81]: Sustainable value co-creation between firm and consumers in bike-sharing projects

Managers and firm workers

[57,69,73]

Energy users and consumers

[71,72,78,81]

Citizen and non-expert

stakeholders

$[56,62,66-68,70,76,77]$

\section{References}

1. IPCC. 2018: Global Warming of $1.5^{\circ} \mathrm{C}$. An IPCC Special Report on the Impacts of Global Warming of $1.5^{\circ} \mathrm{C}$ above Pre-Industrial Levels and Related Global Greenhouse Gas Emission Pathways, in the Context of Strengthening the Global Response to the Threat of Climate Change, Sustainable Development, and Efforts to Eradicate Poverty; Masson-Delmotte, V.P., Zhai, H.-O., Pörtner, D., Roberts, J., Skea, P.R., Shukla, A., Pirani, W., Moufouma-Okia, C., Péan, R., Pidcock, S., et al., Eds.; IPCC: Geneva, Switzerland, 2018.

2. Loorbach, D.; Frantzeskaki, N.; Avelino, F. Sustainability Transitions Research: Transforming Science and Practice for Societal Change. Annu. Rev. Environ. Resour. 2017, 42, 599-626. [CrossRef]

3. Li, F.G.N.; Trutnevyte, E.; Strachan, N. A review of socio-technical energy transition (STET) models. Technol. Forecast. Soc. Change 2015, 100, 290-305. [CrossRef]

4. Geels, F.W.; Schot, J. Typology of sociotechnical transition pathways. Res. Policy 2007, 36, 399-417. [CrossRef]

5. Hess, D.J.; Sovacool, B.K. Sociotechnical matters: Reviewing and integrating science and technology studies with energy social science. Energy Res. Soc. Sci. 2020, 65, 101462. [CrossRef]

6. Sorrell, S. Explaining sociotechnical transitions: A critical realist perspective. Res. Policy 2018, 47, 1267-1282. [CrossRef] 
7. Geels, F.W.; Sovacool, B.K.; Schwanen, T.; Sorrell, S. The Socio-Technical Dynamics of Low-Carbon Transitions. Joule 2017, 1, 463-479. [CrossRef]

8. Geels, F.W.; Schwanen, T.; Sorrell, S.; Jenkins, K.; Sovacool, B.K. Reducing energy demand through low carbon innovation: A sociotechnical transitions perspective and thirteen research debates. Energy Res. Soc. Sci. 2018, 40, 23-35. [CrossRef]

9. Geels, F.W. Micro-foundations of the multi-level perspective on socio-technical transitions: Developing a multi-dimensional model of agency through crossovers between social constructivism, evolutionary economics and neo-institutional theory. Technol. Forecast. Soc. Chang. 2020, 152, 119894. [CrossRef]

10. Svensson, O.; Nikoleris, A. Structure reconsidered: Towards new foundations of explanatory transitions theory. Res. Policy 2018, 47, 462-473. [CrossRef]

11. Kanger, L. Rethinking the Multi-level Perspective for energy transitions: From regime life-cycle to explanatory typology of transition pathways. Energy Res. Soc. Sci. 2021, 71, 101829. [CrossRef]

12. Bögel, P.M.; Upham, P. Role of psychology in sociotechnical transitions studies: Review in relation to consumption and technology acceptance. Environ. Innovat. Soc. Trans. 2018, 28, 122-136. [CrossRef]

13. Goodman, J.; Marshall, J.P. Problems of methodology and method in climate and energy research: Socialising climate change? Energy Res. Soc. Sci. 2018, 45, 1-11. [CrossRef]

14. Upham, P.; Bögel, P.; Dütschke, E. Thinking about individual actor-level perspectives in sociotechnical transitions: A comment on the transitions research agenda. Environ. Innovat. Soc. Trans. 2020, 34, 341-343. [CrossRef]

15. Burke, M.J.; Stephens, J.C. Political power and renewable energy futures: A critical review. Energy Res. Soc. Sci. 2018, 35, 78-93. [CrossRef]

16. Meadowcroft, J. What about the politics? Sustainable development, transition management, and long term energy transitions. Policy Sci. 2009, 42, 323-340. [CrossRef]

17. Feola, G. Capitalism in sustainability transitions research: Time for a critical turn? Environ. Innovat. Soc. Trans. 2020, 35, 241-250. [CrossRef]

18. Sovacool, B.K. What are we doing here? Analyzing fifteen years of energy scholarship and proposing a social science research agenda. Energy Res. Soc. Sci. 2014, 1, 1-29. [CrossRef]

19. Royston, S.; Foulds, C. The making of energy evidence: How exclusions of Social Sciences and Humanities are reproduced (and what researchers can do about it). Energy Res. Soc. Sci. 2021, 77, 102084. [CrossRef]

20. Fawcett, P.; Flinders, M.V.; Hay, C.; Wood, M. (Eds.) Anti-Politics, Depoliticization, and Governance, 1st ed.; Oxford University Press: Oxford, UK, 2017.

21. Geels, F.W. Socio-technical transitions to sustainability: A review of criticisms and elaborations of the Multi-Level Perspective. Curr. Opin. Environ. Sustain. 2019, 39, 187-201. [CrossRef]

22. Köhler, J.; Geels, F.W.; Kern, F.; Markard, J.; Onsongo, E.; Wieczorek, A.; Alkemade, F.; Avelino, F.; Bergek, A.; Boons, F.; et al. An agenda for sustainability transitions research: State of the art and future directions. Environ. Innovat. Soc. Trans. 2019, 31, 1-32. [CrossRef]

23. Sovacool, B.K.; Brisbois, M.-C. Elite power in low-carbon transitions: A critical and interdisciplinary review. Energy Res. Soc. Sci. 2019, 57, 101242. [CrossRef]

24. Kanger, L. Neglected systems and theorizing: A comment on the transitions research agenda. Environ. Innovat. Soc. Trans. 2020, 34, 352-354. [CrossRef]

25. Van Poeck, K.; Östman, L.; Block, T. Opening up the black box of learning-by-doing in sustainability transitions. Environ. Innovat. Soc. Trans. 2020, 34, 298-310. [CrossRef]

26. Van Mierlo, B.; Halbe, J.; Beers, P.J.; Scholz, G.; Vinke-de Kruijf, J. Learning about learning in sustainability transitions. Environ. Innovat. Soc. Trans. 2020, 34, 251-254. [CrossRef]

27. Van Mierlo, B.; Beers, P.J. Understanding and governing learning in sustainability transitions: A review. Environ. Innovat. Soc. Trans. 2020, 34, 255-269. [CrossRef]

28. Gerlak, A.K.; Heikkila, T.; Smolinski, S.L.; Huitema, D.; Armitage, D. Learning our way out of environmental policy problems: A review of the scholarship. Policy Sci. 2018, 51, 335-371. [CrossRef]

29. Goyal, N.; Howlett, M. Who learns what in sustainability transitions? Environ. Innovat. Soc. Trans. 2020, 34, 311-321. [CrossRef]

30. Van Poeck, K.; Östman, L. Learning to find a way out of non-sustainable systems. Environ. Innovat. Soc. Trans. 2021, 39, 155-172. [CrossRef]

31. Billi, M.; Blanco, G.; Urquiza, A. What is the 'Social' in Climate Change Research? A Case Study on Scientific Representations from Chile. Minerva 2019, 57, 293-315. [CrossRef]

32. Sarrica, M.; Brondi, S.; Cottone, P.; Mazzara, B.M. One, no one, one hundred thousand energy transitions in Europe: The quest for a cultural approach. Energy Res. Soc. Sci. 2016, 13, 1-14. [CrossRef]

33. Cole, M. Cultural Psychology: A Once and Future Discipline; Harvard University Press: Cambridge, MA, USA, 1996.

34. Mazzara, B. Prospettive di Psicologia Culturale. Modelli Teorici e Contesti di Azione; Carocci: Rome, Italy, 2007.

35. Biddau, F.; Armenti, A.; Cottone, P. Socio-psychological aspects of grassroots participation in the Transition Movement: An Italian case study. J. Soc. Polit. Psychol. 2016, 4, 142-165. [CrossRef]

36. Kim, H.; Cho, S.H.; Song, S. Wind, power, and the situatedness of community engagement. Public Understand. Sci. 2019, 28, 38-52. [CrossRef] 
37. Sarrica, M.; Biddau, F.; Brondi, S.; Cottone, P.; Mazzara, B.M. A multi-scale examination of public discourse on energy sustainability in Italy: Empirical evidence and policy implications. Energy Policy 2018, 114, 444-454. [CrossRef]

38. Sarrica, M.; Richter, M.; Thomas, S.; Graham, I.; Mazzara, B.M. Social approaches to energy transition cases in rural Italy, Indonesia and Australia: Iterative methodologies and participatory epistemologies. Energy Res. Soc. Sci. 2018, 45, 287-296. [CrossRef]

39. Upham, P.; Eberhardt, L.; Klapper, R.G. Rethinking the meaning of "landscape shocks" in energy transitions: German social representations of the Fukushima nuclear accident. Energy Res. Soc. Sci. 2020, 69, 101710. [CrossRef] [PubMed]

40. Sarrica, M.; Brondi, S.; Piccolo, C.; Mazzara, B.M. Environmental Consciousness and Sustainable Energy Policies: Italian Parliamentary Debates in the Years 2009-2012. Society Nat. Resour. 2016, 29, 932-947. [CrossRef]

41. Pontecorvo, C.; Ajello, A.M.; Zucchermaglio, C. I Contesti Sociali Dell'apprendimento; LED Edizioni Universitarie di Lettere Economia e Diritto: Milan, Italy, 1995.

42. Lave, J. Situating learning in communities of practice. In Perspectives on Socially Shared Cognition; Resnick, L.B., Levine, J.M., Teasley, S.D., Eds.; American Psychological Association: Washington, DC, USA, 1991; pp. 63-82. [CrossRef]

43. Lave, J.; Wenger, E. Situated Learning. Legitimate Peripheral Participation; Cambridge University Press: Cambridge, MA, USA, 1991.

44. Bressers, J.T.; Rosenbaum, W. Innovation, learning, and environmental policy: Overcoming a plague of uncertainties. Policy Stud. J. 2000, 28, 523-539. [CrossRef]

45. Folke, C.; Hahn, T.; Olsson, P.; Norberg, J. Adaptive governance of social-ecological systems. Annu. Rev. Environ. Resour. 2005, 30, 441-473. [CrossRef]

46. Newman, M.; Gough, D. Systematic Reviews in Educational Research: Methodology, Perspectives and Application; Zawacki-Richter, O., Kerres, M., Bedenlier, S., Bond, M., Buntins, K., Eds.; Springer Fachmedien Wiesbaden: Berlin, Germany, 2020. [CrossRef]

47. Gough, D.; Olive, S.; Thomas, J. Introducing systematic reviews. In An Introduction to Systematic Reviews, 2nd ed.; Gough, D., Olive, S., Thomas, J., Eds.; Sage: London, UK, 2017; pp. 1-18.

48. Moher, D.; Liberati, A.; Tetzlaff, J.; Altman, D.G. Preferred Reporting Items for Systematic Reviews and Meta-Analyses: The PRISMA Statement. PLoS Med. 2009, 6, b2535. [CrossRef]

49. Gerring, J. Social Science Methodology: A Framework; Cambridge University Press: Cambridge, MA, USA, 2012.

50. Singleton, R.; Straits, B.R. Approaches to Social Research; Oxford University Press: Oxford, UK, 2005.

51. Sovacool, B.K.; Griffiths, S. The cultural barriers to a low-carbon future: A review of six mobility and energy transitions across 28 countries. Renew. Sustain. Energy Rev. 2020, 119, 109569. [CrossRef]

52. Torgerson, C. Systematic Reviews; Continuum: London, UK, 2003.

53. Sovacool, B.K.; Hess, D.J. Ordering theories: Typologies and conceptual frameworks for sociotechnical change. Soc. Stud. Sci. 2017, 47, 703-750. [CrossRef]

54. Hobson, K.; Mayne, R.; Hamilton, J. Monitoring and evaluating eco-localisation: Lessons from UK low carbon community groups. Environ. Plan. A Econ. Space 2016, 48, 1393-1410. [CrossRef]

55. Kim, J.E. Fostering behaviour change to encourage low-carbon food consumption through community gardens. Int. J. Urban Sci. 2017, 21, 364-384. [CrossRef]

56. Ollis, T.; Hamel-Green, M. Adult education and radical habitus in an environmental campaign: Learning in the coal seam gas protests in Australia. Austr. J. Adult Learn. 2015, 55, 202-219.

57. Heiskanen, E.; Hyvönen, K.; Laakso, S.; Laitila, P.; Matschoss, K.; Mikkonen, I. Adoption and Use of Low-Carbon Technologies: Lessons from 100 Finnish Pilot Studies, Field Experiments and Demonstrations. Sustainability 2017, 9, 847. [CrossRef]

58. Mychajluk, L. Learning to live and work together in an ecovillage community of practice. Eur. J. Res. Educ. Learn. Adults 2017, 8 , 181-196. [CrossRef]

59. Larri, L.; Whitehouse, H. Nannagogy: Social movement learning for older women's activism in the gas fields of Australia. Austr J. Adult Learn. 2019, 59, 27-52.

60. Pacheco, L.; Ningsu, L.; Pujol, T.; Gonzalez, J.R.; Ferrer, I. Impactful engineering education through sustainable energy collaborations with public and private entities. Int. J. Sustain. Higher Educ. 2019, 20, 393-407. [CrossRef]

61. Nawi, N.D.; Phang, F.A.; Mohd Yusof, K.; Abdul Rahman, N.F.; Zakaria, Z.Y.; Syed Hassan, S.A.H.; Musa, A.N. Instilling Low Carbon Awareness through Technology-Enhanced Cooperative Problem Based Learning. Int. J. Emerg. Technol. Learn. 2019, 14, 152. [CrossRef]

62. Upham, P.; Klapper, R.; Carney, S. Participatory energy scenario development as dramatic scripting: A structural narrative analysis. Technol. Forecast. Social Chang. 2016, 103, 47-56. [CrossRef]

63. Ollis, T.A. Adult learning and circumstantial activism in the coal seam gas protests: Informal and incidental learning in an environmental justice movement. Stud. Educ. Adults 2020, 52, 215-231. [CrossRef]

64. Andreotta, C. Visioneering futures: A way to boost regional awareness of the low-carbon future. Region. Stud. Region. Sci. 2018, 5, 117-124. [CrossRef]

65. Hoppe, T.; Graf, A.; Warbroek, B.; Lammers, I.; Lepping, I. Local Governments Supporting Local Energy Initiatives: Lessons from the Best Practices of Saerbeck (Germany) and Lochem (The Netherlands). Sustainability 2015, 7, 1900-1931. [CrossRef]

66. Heiskanen, E.; Jalas, M.; Rinkinen, J.; Tainio, P. The local community as a "low-carbon lab": Promises and perils. Environ. Innovat. Soc. Trans. 2015, 14, 149-164. [CrossRef]

67. Groulx, M.; Fishback, L.; Winegardner, A. Citizen science and the public nature of climate action. Polar Geogr. 2019, 42, 176-195. [CrossRef] 
68. Upham, P.; Virkamäki, V.; Kivimaa, P.; Hildén, M.; Wadud, Z. Socio-technical transition governance and public opinion: The case of passenger transport in Finland. J. Transp. Geogr. 2015, 46, 210-219. [CrossRef]

69. Bratton, A. The role of talent development in environmentally sustainable hospitality: A case study of a Scottish National Health Service conference centre. Worldw. Hosp. Tourism Themes 2018, 10, 69-85. [CrossRef]

70. Sharp, D.; Salter, R. Direct Impacts of an Urban Living Lab from the Participants' Perspective: Livewell Yarra. Sustainability 2017, 9, 1699. [CrossRef]

71. Van der Grijp, N.; van der Woerd, F.; Gaiddon, B.; Hummelshøj, R.; Larsson, M.; Osunmuyiwa, O.; Rooth, R. Demonstration projects of Nearly Zero Energy Buildings: Lessons from end-user experiences in Amsterdam, Helsingborg, and Lyon. Energy Res. Soc. Sci. 2019, 49, 10-15. [CrossRef]

72. Alade, T.; Edelenbos, J.; Gianoli, A. Frugality in multi-actor interactions and absorptive capacity of Addis-Ababa light-rail transport. J. Urban Manag. 2020, 9, 67-76. [CrossRef]

73. Rosenbloom, D.; Meadowcroft, J.; Sheppard, S.; Burch, S.; Williams, S. Transition Experiments: Opening Up Low-Carbon Transition Pathways for Canada through Innovation and Learning. Canad. Public Policy 2018, 44, 368-383. [CrossRef]

74. Barazza, E.; Strachan, N. The co-evolution of climate policy and investments in electricity markets: Simulating agent dynamics in UK, German and Italian electricity sectors. Energy Res. Soc. Sci. 2020, 65, 101458. [CrossRef]

75. Kotilainen, K.; Aalto, P.; Valta, J.; Rautiainen, A.; Kojo, M.; Sovacool, B.K. From path dependence to policy mixes for Nordic electric mobility: Lessons for accelerating future transport transitions. Policy Sci. 2019, 52, 573-600. [CrossRef]

76. Stoll-Kleemann, S.; O'Riordan, T. Revisiting the Psychology of Denial Concerning Low-Carbon Behaviors: From Moral Disengagement to Generating Social Change. Sustainability 2020, 12, 935. [CrossRef]

77. Bruine de Bruin, W.; Mayer, L.A.; Morgan, M.G. Developing communications about CCS: Three lessons learned. J. Risk Res. 2015, 18, 699-705. [CrossRef]

78. Hogarth, J.R. Evolutionary models of sustainable economic change in Brazil: No-till agriculture, reduced deforestation and ethanol biofuels. Environ. Innovat. Soc. Trans. 2017, 24, 130-141. [CrossRef]

79. Nikkels, M.J.; Guillaume, J.H.A.; Leith, P.; Mendham, N.J.; van Oel, P.R.; Hellegers, P.J.G.J.; Meinke, H. Participatory Crossover Analysis to Support Discussions about Investments in Irrigation Water Sources. Water 2019, 11, 1318. [CrossRef]

80. Wiegink, N. Learning lessons and curbing criticism: Legitimizing involuntary resettlement and extractive projects in Mozambique. Polit. Geog. 2020, 81, 102192. [CrossRef]

81. Lan, J.; Ma, Y.; Zhu, D.; Mangalagiu, D.; Thornton, T. Enabling Value Co-Creation in the Sharing Economy: The Case of Mobike. Sustainability 2017, 9, 1504. [CrossRef]

82. Goertz, G. Social Science Concepts: A User's Guide; Princeton University Press: Princeton, NJ, USA, 2005.

83. Pike, K.L. Etic and emic standpoints for the description of behaviour. In Communication and Culture; Smith, A.G., Ed.; Van Nostrand: The Hague, The Netherlands, 1966.

84. American Psychological Association. American Psychological Association Dictionary. Available online: https://dictionary.apa. org/agency (accessed on 23 June 2021).

85. Thaler, R.H.; Sunstein, C.R. Nudge: Improving Decisions about Health, Wealth, and Happiness; Penguin: London, UK, 2009.

86. Gigerenzer, G. Fast and frugal heuristics: The tools of bounded rationality. In Blackwell Handbook of Judgment and Decision Making; Koehler, D., Harvey, N., Eds.; Blackwell: Oxford, UK, 2004; pp. 62-88.

87. Giardullo, P.; Pellizzoni, L.; Brondi, S.; Osti, G.; Bögel, P.; Upham, P.; Castro, P. Connecting Dots: Multiple Perspectives on Socio-technical Transition and Social Practices. Ital. J. Sci. Technol. Stud. 2020, 10, 121-152.

88. Wood, M.; Flinders, M. Rethinking depoliticization: Beyond the governmental. Policy Polit. 2014, 42, 151-170. [CrossRef]

89. Hay, C. Why We Hate Politics; Polity Press: Cambridge, UK, 2007.

90. Beverige, R.; Naumann, M. Global norms, local contestation: Privatisation and de/politicisation in Berlin. Policy Politics 2014, 42, 275-291. [CrossRef]

91. Santos, T.R.; Castro, P.; Guerra, R. Is the press presenting (neoliberal) foreign residency laws in a depoliticised way? The case of investment visas and the reconfiguring of citizenship. J. Soc. Polit. Psychol. 2020, 8, 748-766. [CrossRef]

92. Kuzemko, C. Energy Depoliticisation in the UK: Destroying Political Capacity. Br. J. Polit. Int. Relat. 2016, 18, 107-124. [CrossRef]

93. Kvidal-Røvik, T. Nature Articulations in Norwegian Advertising Discourse: A Depoliticized Discourse of Climate Change. Environ. Commun. 2018, 12, 794-806. [CrossRef]

94. Gailing, L.; Moss, T. (Eds.) Conceptualizing Germany's Energy Transition; Palgrave Macmillan: London, UK, 2016. [CrossRef]

95. Cech, E.; Sherick, H.M. Depoliticization and the Structure of Engineering Education. In International Perspectives on Engineering Education; Veermas, P.E., Ed.; Springer: Berlin, Germany, 2015.

96. Lucena, J. (Ed.) Engineering Education for Social Justice; Springer: Dordrecht, The Netherlands, 2013; Volume 10. [CrossRef]

97. Smerecnik, K.R.; Renegar, V.R. Capitalistic Agency: The Rhetoric of BP's Helios Power Campaign. Environ. Commun. 2010, 4, 152-171. [CrossRef]

98. Souza, D.T.; Wals, A.E.J.; Jacobi, P.R. Learning-based transformations towards sustainability: A relational approach based on Humberto Maturana and Paulo Freire. Environ. Educ. Res. 2019, 25, 1605-1619. [CrossRef]

99. Romaioli, D.; Contarello, A. Redefining agency in late life: The concept of 'disponibility'. Ageing Soc. 2019, 39, 194-216. [CrossRef] 